\title{
ANATOMOPATHO-LOGICAL STUDY OF COMPLICATION OF TUBERCULOSIS SEEN IN HUMAN LEPROSY (REPORT II)
}

\author{
KIMIO TAKANO \\ Bethlehem Sanatorium (Director: Dr. K. FUJII) \\ (Directed by Emeritus Prof. T. OGATA, Counsellor of National Institute for Leprosy Research)
}

The state of complication of tuberculosis in leprosy and the relation between leprosy and tuberculosis according to the disease types was further examined by histo-patho-anatomical examination as in Report I, of all the 450 autopsy cases of the National Oshima Seisho-en Leprosarium from 1924 to 1959.

Further, the process of the disease was examined by dividing into 3 stages, taking into consideration the influence of the period and of chemotherapy; that is, 1) before the introduction of chemo-therapy (stage of hydnocarpus oil therapy) (1924-1942)...before World War II ; 2 after introduction of chemo-therapy (1943-1950) $\cdots$ during and directly after the War;

3) after chemo-therapy (1951-1959) …after the War.

Conclusion :-

1) Out of the 450 cases, there were 313 cases of the L-type (64.3\%) and 137 cases of the T-type (30.6\%), the L-type being over 2.3 times that of the T-type.

2) The percentage of combined tuberculosis was $77.2 \%$ (347 cases out of 450 ), $80.5 \%$ in the L-type (252/313), and 69.6\% (95/137) in the T-type. Further, of the 252 cases of combined tuberculosis in the L-type, $84.3 \%$ was found in those before the war, 56.4\% during the war, and $80 \%$ in those after the war; and of the 95 cases of combined tuberculosis in the $\mathrm{T}$-type, the percentage was $70.8 \%, 76.6 \%$, and $53 \%$ respectively, tuberculosis being found in more than half in both types.

3) As for the foci of secondary tuberculosis, similar to Report I, they were found in all the L-type cases. Moreover, in the T-type, 24\% were healed in the stage of primary foci ofthe lungs, while $16 / 74,21.3 \% \cdots$ before the War; $13 / 45,30 \% \cdots$ during the war; and $3 / 8,37.5 \% \cdots$ after the War, i.e. over one-third were healed in the stage of primary foci of the lungs.

4) As for the frequency of tuberculosis, there were about $70 \%$ of severe cases in both L-, and T-types in the period before the War, but with the passage of years the absolute number of patients is decreasing conspicuously. In the L-type, severe cases of tuberculosis were found in 76.7\% before the War, 81.8\% during the War, and 56.3\% after the War; while in the T-type it was found in $63.8 \%, 30.8 \%$, and $12.5 \%$ respectively during the above periods, showing a marked decrease, being only $50 \%$ of the L-type in the latter half period. Many severe cases could be seen in both types, but with the progress of chemotherapy, the spread of BCG vaccination, and the improvement of nutrition, the mortality of both 
leprosy and tuberculosis patients have shown a marked decrease.

The same tendency as seen in Report I was also confirmed, that is to say, the L-type which has a weak resistance towards leprosy has also a weak resistance towards tuberculosis, while the T-type more resistant towards leprosy, possesses a strong resistance towards tuberculosis.

\title{
人癩屍に合併した結核症の病理解剖学的 研究 第? 報
}

\author{
高野公雄 \\ ベトレへムの園療養所（院長 藤井清之）
}

（指導 国立らい研究所顧問 緒方知三郎博士）

\section{緒言}

著者は第 1 報において報告せる如く類結核型瀨が合併 結核を著しく抑制していると言う結論を得たが，なお剖 検観察例十分ならざるため今回は症例を追加し，第 1 報 の諸事実を確認与ると同時に化学療法前後の癩患者の結 核合併状沉を考察せんがために，国立療養所大島青松園 の大正13年（1924）より昭和34年（1959）にいたる35年 間の保存全剖検材料 450 例について第 1 報に準じ検索を 行つた。

\section{材料及び方法}

上記大正.13年より昭和 34 年字での全剖検例 490 例中不 詳, 非攋例合計 40 例を除く 450 例を次の 3 期に従つて分 類し化学療法(4)-29), 及び社会状態などの影響を考慮しつ つ観察を進めた（表 1 及び 2 ）。

1. 化学療法以前（大風子油時代）, 大正13年 (1924) より昭和16年 (1942)（18年間）第二次大戦前 359 例。

2. 化学療法以前 ( " ) : 昭和 17 年（1943年）よ り同25年（1950）（9年間）大戦中及び直後 56 例。

3. 化学療法以後：昭和25年 (1951) 上り同34年 (19 59）（5年間）大戦後 35 例。

さらに個々の剖検例の検索方法は第 1 報に同じであ る。

\section{成 績}

I 剖検材料の癩病型別比率（表 1 及び 2)：

全剖検例 450 例中 $\mathrm{L}$ 型は総計 313 例，69.4\%， $\mathrm{T}$ 型は
137 例, $30.6 \%$ で $\mathrm{L}$ 型と $\mathrm{T}$ 型の比は $313: 137$ で, $\mathrm{L}$ 型は $\mathrm{T}$ 型の約 2.3 倍であつた。治療年代別に見ると（表 2 ） 大風子油時代の戦前期では両型の比率は $\mathrm{L}$ 型は同期内全 剖検例 359 例中 254 例, $70.6 \%, \mathrm{~T}$ 型は同じく 359 例中 105例, $29.4 \%$, 大風子油時代の戦中期では L 型 39/56, 65.6\%， $\mathrm{T}$ 型 17/56，30.4\% で両型の比率は特に差異を 示さない。化学療法以後では $\mathrm{L}$ 型 20/35, $57.1 \%, \mathrm{~T}$ 型 15/35， $42.9 \%$ と両型がほぼ全体の半数に近くなつてき ている。

II 全癩屍結核合侀率並びに治療年代別的観察：(表1 灭び 2)

結核合併例诖全材料 450 例中 347 例, $77.2 \%$ あ゙る。 時代別に見ると戦前 $288 / 359,80.3 \%$ ，戦中 $35 / 56,62$. $5 \%$, 戦後 $24 / 35,68.6 \%$ と時代とともに減少の傾向を 示したが12)，以来一般非瀨者結核合併並びに死亡率の 減少とほぼ平行している。

III 癞病型別結核合併率：L型, 全剖検例 313 例中結 核合併例 252 例, $80.5 \%$, $\mathrm{T}$ 型全剖㭘例 137 例中結核合 併例 95 例, $69.6 \%$, 年代別化以 L 型戦前 $214 / 254,84.3$ $\%$, 戦中 $22 / 39,56.4 \%$, 戦後 $16 / 20,80.0 \%, \mathrm{~T}$ 型戦前 $74 / 105,70.8 \%$, 戦中 $13 / 17,76.7 \%$, 戦後 $8 / 15,68.6 \%$ と L 型と $\mathrm{T}$ 型との結核合併はともに 70 ～ $80 \%$ 内外であ つた。

IV 初期変化群について（表 2 及び 3 ):

A 全時代を通じて L 型では初期変化群のみにて治瘾也 る例は全くなく，炎の全例が二次絬核に移行するのを認 的た。

B T 型では結核合例例 95 例中 23 例で, お抒む称硬固 
な小豆大以下の石灰化巣, 被包瘢痕化以外に特に病変の 認められない初感染单及び初期変化群のみにて完治を示 していた。

C $\mathrm{T}$ 型の初期変化群は時代別には戦前 16/74, 21.3\%， 戦中 $4 / 13,30.8 \%$, 戦後 $3 / 8,37.5 \%$ と檢出率はやや上 昇を示した。

$\mathrm{V}$ 二次絬核症について:

A 二次結核進展率：L型では結核合併の全例が二次結 核へ進展しており初期变化群のみにて治瘾せる例を認め なかつた。

B 病型別的考察。戦前は重症例が $\mathrm{L}$ 型 164/214, 76.6 $\% \mathrm{~T}$ 型 $47 / 74 ， 63.8 \%$ と両型とも過半数を占めるが，以 後 L 型は戦中 $18 / 22,818 \%$ ，戦後 $9 / 16 ， 56.3 \%$ と幾分減 少の傾向があるに反し， $\mathrm{T}$ 型重症例は戦中 $4 / 13,30.8 \%$ 戦後 $1 / 8,12.5 \%$ と絶対数の低下とともに著明な減少を 示し, 軽症例は $\mathrm{L}$ 型戦前 $35 / 214,16.3 \%$, 戦中 $4 / 22$, $18.2 \%$, 戦後 $5 / 16,31.3 \%$ と約 2 倍の増加を示すが, T 型では戦前 $2 / 74,2.7 \%$, 戦中 $2 / 13,15.5 \%$, 戦後 $2 / 8$ $25 \%$ と著明な軽症増加の傾向を示した。

重症例では L 型で戦前には肺瘵 104例，腸結核性腹膜 炎 21 例，腎結核 5 例，喉頭結核 5 例，骨結核 2 例，結核 性脸膜炎 5 例, 全身粟粒結核 9 例で計 164 例, $76.6 \%$ に 対し $\mathrm{T}$ 型では肺㾜 32 例, 腸結核兼結核性腹膜炎 3 例, 喉頭結核 5 例，骨結核 3 例，結核性脳膜炎 1 例，栗粒結 核 3 例, 計 52 例, $54.7 \%$ でこの時代の結核多量死亡例 が後半の钼祭例及び比率に大きな影響を与えている。

\section{小 括}

I 癩屍病型の比率は L 型 313 例, $\mathrm{T}$ 型 137 例で, $\mathrm{T}$ 型 の 2 倍強であつた。

II 結核合併㤬全剖検例 450 例中 347 例, $77.2 \%$, 約 8 割弱であつた。病型別には L 型は全例 313 例中合併 252 例 $(80.5 \%) ， \mathrm{~T}$ 型は全例 137 例中 95 例（69.6\%）であ つた。治療年代別に見ると両型とも結核合併率は結核患 者絶対数の減少とともに次第に減少の傾向が見られるが 両型間に特に有意義の差を見出さなかつた。

III 結核病勢, 進行状態については L 型では戦前, 戦 後を通じて初期変化群のみにて治瘾せし例は全くなく全 例が二次的結核に進展増悪せるに反し， $\mathrm{T}$ 型では化学療 法以前においてさえ初期変化群のみにみて治瘾せる例は $16 / 74,21.3 \%$ の高率を示し，以後戦中 $4 / 13,30.8 \%$, 戦後 $3 / 8,37.5 \%$ と治㾍傾向の増大を示しており， $\mathrm{T}$ 型 において結核の抑制が極めて著明であつた。

IV 攋屍合并結核は一般非癩結核と同様に重症例が減 少している为，特に $\mathrm{T}$ 型では重症例は戦前の $63.3 \%$ 上
り戦後 $12.5 \%$ と激減し, 軽症例は戦前 $2.7 \%$ より戦後 $25 \%$ 約 10 倍の増加を示した。

\section{総括並びに考案}

以上により第 1 報及び第 2 報での両観察群を一括して 考案を加光る。

I 攋屍での瀨病型分類

観察材料での癩病型別の比，即ち，類結核型対癩腫型 は第 1 報（らい研群） 1 対 2.1 , 第 2 報（大島青松園群） 1 対 2.3 と近似している。これを日本全国癩療養所収容 患者 ${ }^{3)}$ に比較すると，本報の類結核型は低率を示すが， 大体，本邦の癩病型別を代表しているものと考えたい。

II 癩患者の結核合併率は両群とも 7 割から 8 割強で 一般非癩結核と大差注ない。1) 結核の死亡例が 攋と共に 年々著しく減少して行く事は一般社会状勢の好転, 化学 療法の進歩, B C G 接種の普及などによるものである事 はいらまでもない。

III 癩病型別では結核合併は共に 7 割強でほぼ同率で あつた。即ち結核感染の機会は癩病型に関係なく同率で ある。

IV 癩腫型癩にはとの全例が二次結核へ移行し一般に 重症例多く，初期変化群のみで治癒する例を全く見な い。即ち，瀨腫型は結核が類結核型に比して著るしく重 篤である。一方，類結核型は初期変化群のみで完治する ものが多く, 著るしく結核学抑制しており, 特に化学療 法以後は類結核型の合併結核重症例は激減し同時に初期 変化群のみにて治瘾例の増加が著明であつた。しかし化 学療法以前に注両型とも重症例分全結核合併例の約半数 を占める。この点大正〜昭和初期の癩診断が適確である や否か再考を要するものである。

$\mathrm{V}$ 癩化学療法前後の結核合併状沉の比較（表 4）

大島青松園群中戦前の癩解剖例 359 例と, 戦後即ち昭 和 26 年以後の大島青松園群 35 例亡らい研群 66 例との合 計 101 例とについて，化学療法の全く行なわれない時代 と, 比較的普及した時代における人攋での結核合併状 沉, 特に結核の進展を癞病型別に比較すると, 結核合併 率は, 戦前は $80.2 \%$, 戦後は $70.3 \%$ で $10 \%$ 減少して いる。癩腫型では戦前 214 例, 戦後 48 例中 $100 \%$ 即ち 全例が二次的結核に進展しているのに反し，類結核型で は戦前の結核合併例 74例 (70.8\%) 中 $21.3 \%$ (16例) が，また戦後 23 例の結核合併例中 $65.2 \%$ (15例）がとも に初期変化群のみで治瘾している。

初期変化群の文で完治した類結核型は戦後はらい研群 では 8 割の高率を示し，また，大島群を加光ても 6 割 5 分の高率である事は注目すべき現象であり，化学療法の 
影響も考慮さ机るが，同療法の出現していない戦前にお いてすら 2 割強が初期変化群のみで完治している事実は 化学療法のみの影響でない事を強く物語り，（二次的神 経瀬を類結核型に入れていた昔口の癩診断を再吟味すれ ば更に高率を示すであうう）類結核型瀨が本質的に結核 を抑制している事を確実に実証しているものである。

VI 癩屍の結核病勢判定の臨床的考慮：

癩腫型では結核が類結核型に比して重应の傾向がみら れた事から癩腫型のみに大きく作用する特別の誘因とし て E .N.L．に注目する必要がある。E．N．L．（㻗性結 節性紅斑）による高熱食愁不振，また神経痛による不眠 なぞ結核増悪团子を考慮すべきであるが特に E . N . L . の記載が不充分であつたため今回は割愛した。なお，臨 床的結核所見と本結論が意外に隔つているか，この点 $\mathrm{X}$ 線陰影他と実際の所見が一致せ奴事は当然であるので, この点は解剖例の増加と共に真実と明らかにされるもの である。

VII 㿎菌に対し抵抗の弱い癩腫型は結核菌に対しても 抵抗弱 $<$, 癩菌に対して抵抗性の強い類結核型では結核 に対しても抵抗性強く，合併せる結核を著しく抑制して いるという結論を得た。

この事は人型結核菌，鼠䅎菌によるマウス及びラッテ における交文免疫実験 ${ }^{28)} 29$ においても組織学的に証明也

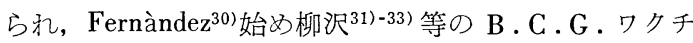
ン接種により癩発病の予防が可能であるといら諸報告, 阿部 ${ }^{34)}$ による人型結核菌と癩菌の両者に多くの共通の抗 原性が認为られている事などから本観察例において免疫 学的にも矛盾なく一致している。

また組織学的所見からも瀨と結核とが mycobacteria 症として同一生体反応に属し, 緒方 ${ }^{35)}$, 福士 ${ }^{36)}$, 湯川 ${ }^{377}$ ${ }^{38)}$, 飯高 ${ }^{39)}$, 高野, 赤崎 ${ }^{40)}$ 等の鼠癭, 人結核, 鳥結核に 関する諸実験から瀬腫に代表される共生相が免疫, 細網 内皮系の機能充進及び体質により増殖性結核に代表され る類上皮細胞性肉芽腫，即ち肉芽相に移行し，また济出 性結核や E . N . L .で代表される渗出壊死相が前壊した 菌体内成分並びに抗原抗体反灾の結果として屾現し，こ 㣗等三病相は生体内に侵入した菌の耐久性並びに免疫, 細網内皮系の機能及び体質等の生体の抵抗力との 2 要因 に上り互に移行するといら諸事実から考察しても前述の 結論は全く適応さ扟得るものである。

本㭘査群の絬核病変は一般結核と異り癩性病变と結核 性病変の中間あるいは移行を示す興味ある所見が見られ たが日を改的て報告する予定である。

\section{結 論}

国立らい研究所病理学研究室における昭和 30 年 7 月以 来 3 年間の全剖検例66例及び国立療養所大島青松園の大 正13年より昭和 34 年 4 月まで 35 年間の全剖検例 450 例合 計 556 例について病理解剖学並びに病理組織学的に癩と 合併せる結核を検索した。癩の両病型の結核合解率は共 に 7〜8 割にしてほぼ同率であるが, 癩腫型では全例が 二次結核へ移行し, 類結核型では化学療法以前に 2 割, 同療法以後で 6 〜 割が初期变化群のみで完治している という事実を得た。

以上により癩菌に対し抵抗性の強い類結核型は攋菌に 対し抵抗性の弱い瀨腫型よりも一層結核菌に対して抵抗 性が強く, 攋腫型に比して著しく結核を抑制していると いう事実を得た。

（本論文の要旨は一部第15回医学総会学術集会シンポ ジウム“癩と結核との関連性”に打いて東大名誉教授緒 方知三郎博士により発表された。また第 1 報は第32回口 本攋学会総会 $(1959,31)$ 及び第 2 報は第 7 回日本癩学. 会東部地方会（1959．9.27.）に打いて発表した。）

（稿をおえるに当り御指導賜りました国立らい研究所 顧問緒方知三郎博士, 同研究所病理学研究公の福士勝成 先生に深い感謝の意をささげます。なお同研究所所長小 林六造博士，同研究部長義江義雄博士，同教室技術員の 川津邦雄, 中村東海両君, 国立療養所大島青松園園長野 島泰治博士, 同検査室植村許子主任, ベトレへムの園院 長藤井清之博士の御尽力に厚く御礼討し上げます。

（癩の病理解剖学的研究 第 7 報）

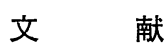

1）結核予防会：結核の統計（同会編集）(1958）

2）尾村偉人：第 15 回日本医学会総会学術集会報告集 1959,（未刊)

3）藤楓協会：日本のらいについて (同会編集) 26〜41 (1958)

4) 堂野前維摩郷他: 最新医学 772 (1952)

5）勝見秀也：レプラ 24137 (1955)

6）屝川一夫：医療 7213 (1953)

7）谷村忠保他：レプラ 20203 (1951)

8）安元健览：同誌，106（1951）

9) Avelino, M. A. abst., VII Intern. Congr. lepr. (1959)

10) Bacaedda-Boy, A. and Farris, G. B.: Ibid.

11) Giuseppe, B. B. : Ibid. 
12) Buv-Hoi, N. P. etal. : Ibid.

13) Hirano, N. etal. : Ibid.

14) Rolaior, R., etal : Ibid.

15) Schimid, K., etal.: Ibid.

16）平野憲正他：レプラ 25136 (1956)

17）西村真二他：同誌 25190 (1956)， 24283 , 402 (1955), $2374,123,345$ (1954) , 22250 (1953) , 2126 (1952)

18）市原鶴男他：同誌 2433 (1955)

19）高山保郎：同誌 2371 (1954)

20）高山保郎他：同誌 2218 (1953)

21）吉永敏夫他：同誌 2368 (1954)

22）安元健児：同誌 2123 (1952)

23）上川豊：同誌 11 1 (1940)

24）日下修一：同誌 8633 (1937)

25）佐谷有吉他：同誌 5229 (1934)

26）太田正雄他：同誌５２04（1934）

27）桜井方策：同誌 4571 (1933)

28）西村真二他：同誌 2570 (1956)

29）中村武雄：同誌 167 (1947)

30) Fernandez, J. M. M. : Intern, J. Lepr, 23243 (1955)

31）柳沢 譜：胸部疾患 3151 (1958)

32) " : 第 7 回国際癩学会抄 (1958)

33) " : レプラ 2670 (1957), 27242 (19 58)

34) 阿部正英：第15回日本医学総会学術集会報告集(未 刊) (1959)
35）緒方知三郎：同誌 57 (1959)

36）福士勝成, 湯川 智, 高野公雄, 飯高和子：日病会 誌 (総会号) 48 (未刊)

37）湯川 智, 福士勝成: 同誌 47420 (1958)

38）湯川 智：同誌 48 (1959) (未刊)

39）飯高和子: 東京女医大誌 $29242 ， 343 ， 455$ (19 59)

40）赤崎兼義：第 15 回日本医学会総会学術集会報告集 261 (1959)

\section{写 真 説 明}

Fig. (1) 剖検例 R-22, 62 才, $\widehat{\delta}, \mathrm{T}$ 型（初期変化群の みにて治瘑例）矢印は石灰化巣を示す。

(2) 剖検例 $\mathrm{R}-2,81$ 才， $\hat{\delta}, \mathrm{T}$ 型 (中等症) 矢印は小指頭大の空洞

(3) 剖検例 $\mathrm{R}-29,32$ 才， $\mathrm{L}$ 型（中等庭） 矢印は小指頭大の空洞，誘導気管支㐫り，融解 乾酪栄, 小石灰巣など混在し, 肋膜肥厚中等 度，矢印(口)は初感染栄

(4) L 型, (中等症例,) 矢印(1)は初感染巣? (口)は リンパ腺軟化，(》は肋膜肥厚

(5) L 型, 重症肺栗粒結核例, 矢印( 价は栗粒結節多 発, (口) は肋膜肥厚

"6(7) 重症荒燕肺を示す。知印は 1 側肺全野の巨大 空洞を示す。

8) L 型, (重症例) 矢印 (1) は廻盲部洀痕性㹨窄,

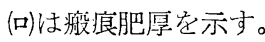




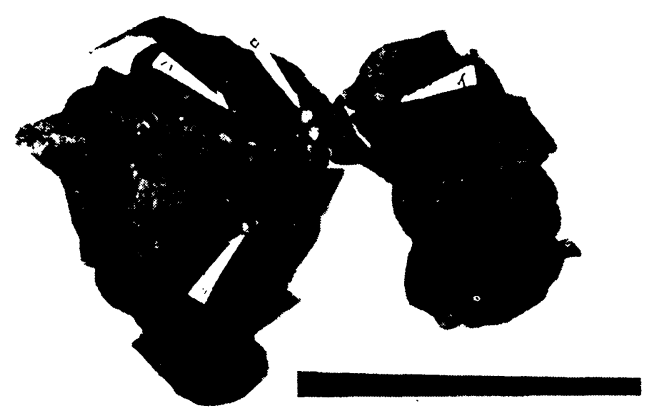

Fig. 1

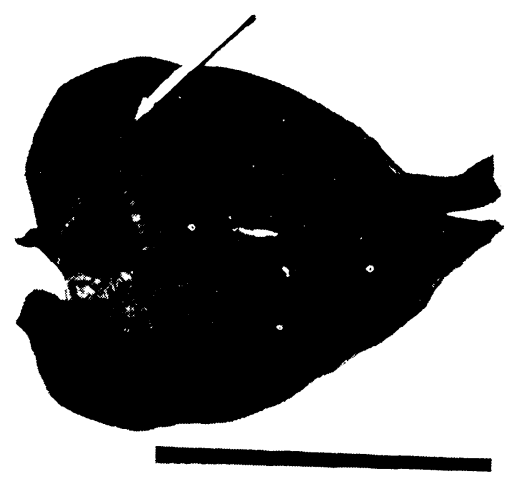

Fig. 2
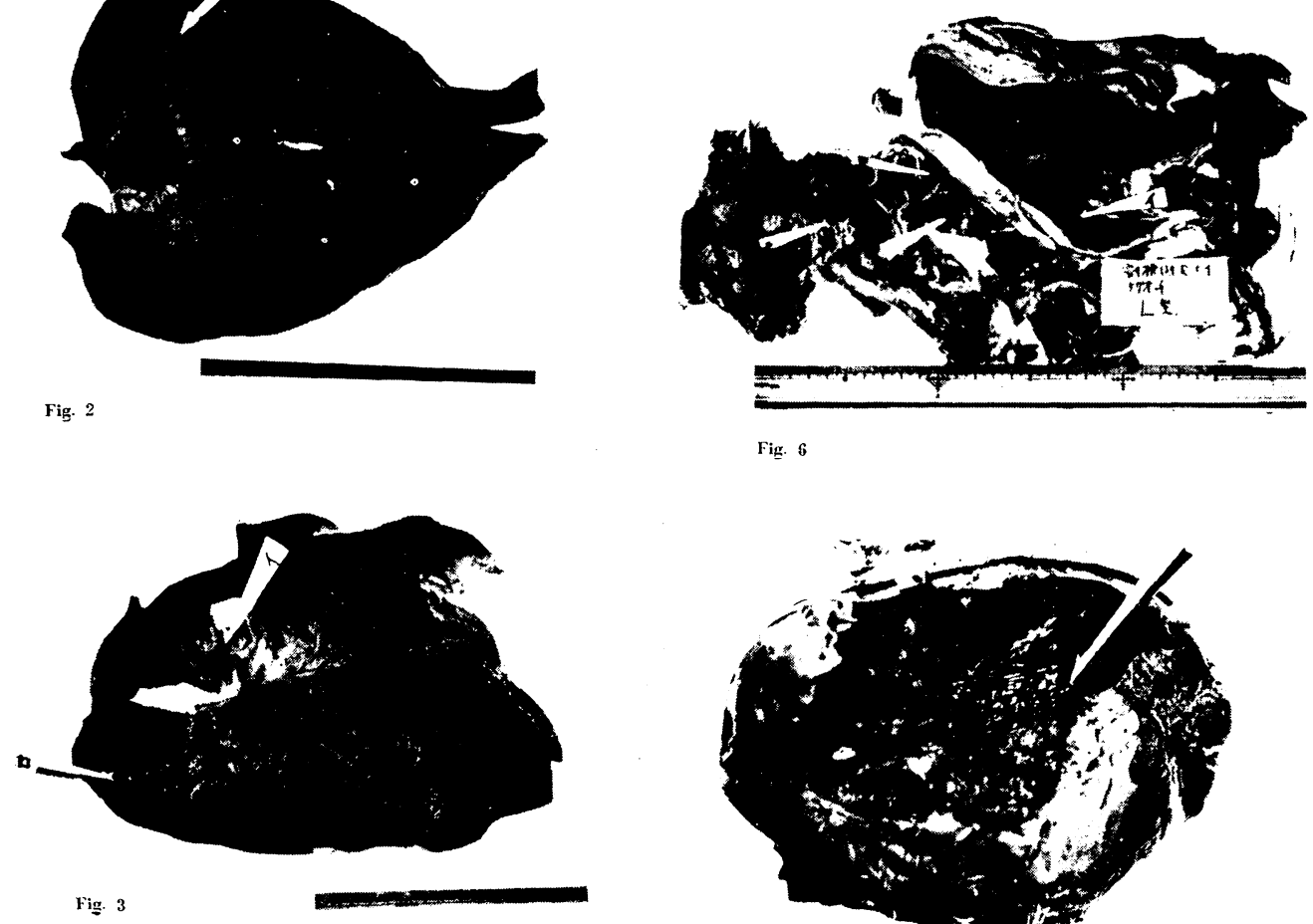

Fig. 6

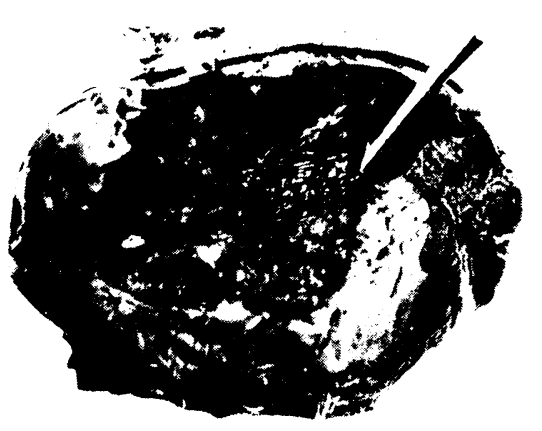

Fig. 7
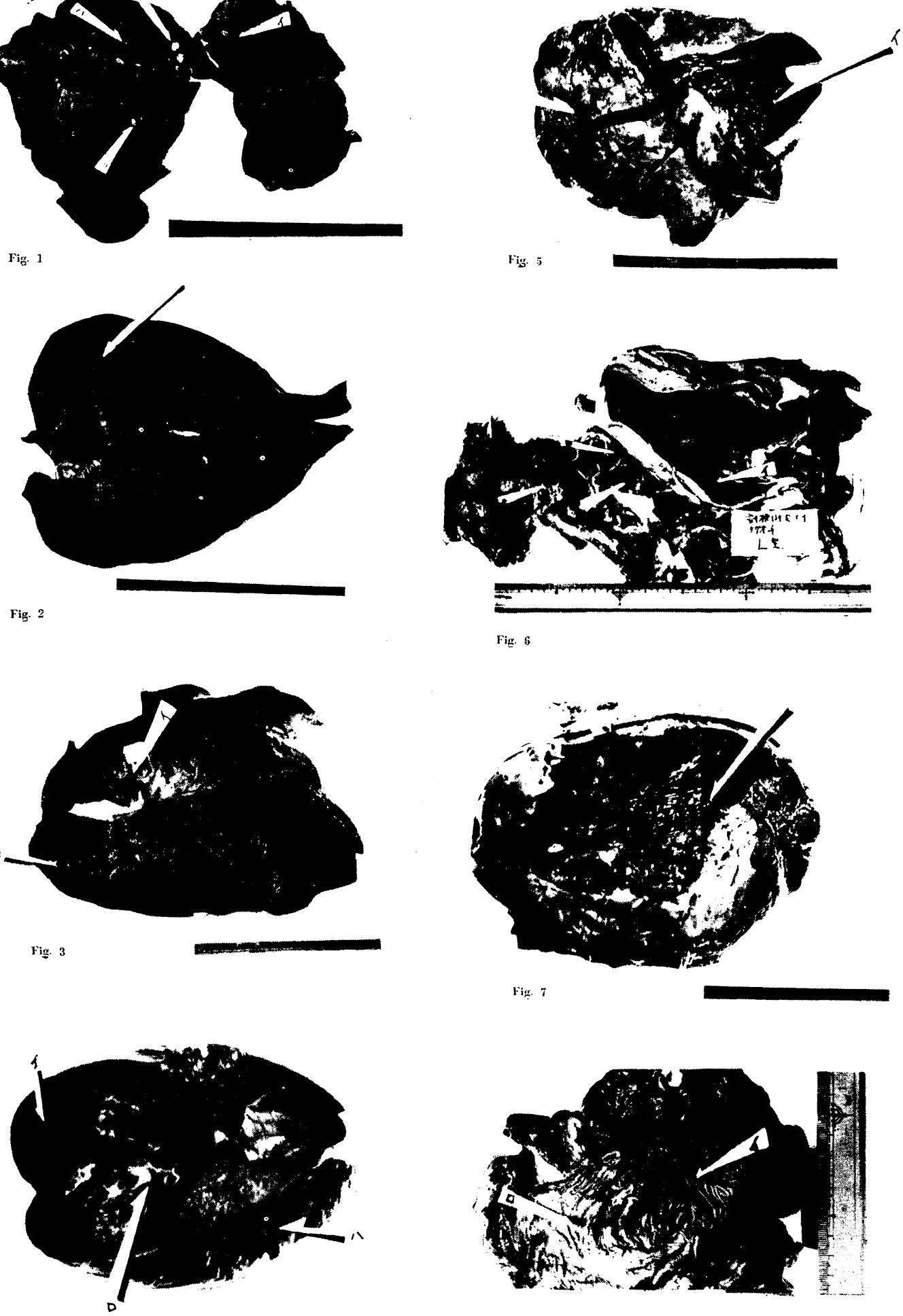

Fig. 4

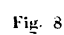


表 1 症 例 一 覧（国立療養所大島青松園全剖検例 490 例について）

咅 治：初感染楽のみにて治揞せるもの

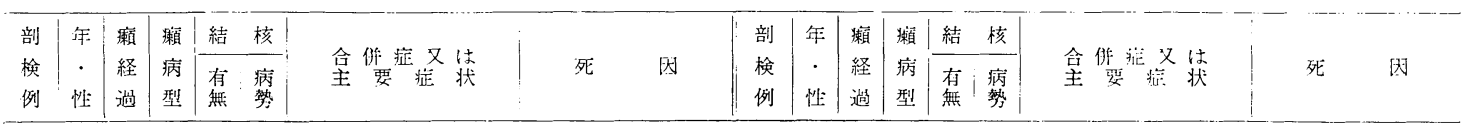

大正 13 年 $\sim$ 昭和 16 年

(計 377 例)

\begin{tabular}{|c|c|c|c|c|c|c|c|c|c|c|c|c|c|c|c|c|}
\hline 1 & $34 \hat{\delta}$ & $\begin{array}{c}\text { 年 } \\
29\end{array}$ & $\mathrm{~T}$ & + & 重 & 粟粒結核 & 肺結核 & & 42 & $26 \hat{\text { s }}$ & $\begin{array}{l}\text { 年 } \\
9\end{array}$ & $\mathrm{~T}$ & + & 重 & 助, 胻膛炎 & 肺結核 \\
\hline 2 & 39 今。 & 11 & $\mathrm{~T}$ & + & 治 & 僧帽弁閉銷全 & 流感 & & 43 & 24 . & 8 & $\mathrm{~T}$ & + & 重 & 晹結核 & 肺結核 \\
\hline 3 & $32 \hat{o}$ & 12 & $\mathrm{~L}_{3}$ & - & & 動脈硬化 & 弁膜病: & & 44 & $30 \delta$ & 6 & $\mathrm{~L}_{3}$ & - & & & 唉站狄窄 \\
\hline 4 & $37 \hat{\delta}$ & 23 & $\mathrm{~L}$ & +1 & 重 & 助, 腹膜炎 & 沏結核 & & 45 & 35 o & 7 & $\mathrm{~L}_{3}$ & + & 重 & 粟粒結核 & 腓結㤥 \\
\hline 5 & 50 今 & 46 & $\mathbf{L}$ & $"$ & 重 & 粟粒結核 & $"$ & & 46 & 20 今 & 14 & $\mathrm{~L}$ & + & 重 & 粟粒結核 & 肺結核 \\
\hline 6 & 36 숭 & 20 & $\mathbf{T}$ & -1 & & (腹水) & 慢性腎炎 & & 47 & 25 & 7 & $\mathrm{~L}$ & + & 重 & 符椎カリエス & 肺結核 \\
\hline 7 & $36 \hat{o}$ & 18 & $\mathbf{L}$ & + & 中 & (胸水) 肺結核 & $"$ & & 48 & 48 & 7 & $\mathrm{~L}$ & + & 硁 & & 衰弱 \\
\hline 8 & $52 \hat{\circ}$ & 16 & $\mathrm{~L}_{3}$ & $"$ & 軽 & & $"$ & & 49 & 26 + & 16 & L & - & & & 腸カタル \\
\hline 9 & 63 우. & 18 & $\mathrm{~T}$ & - & & & 晹 炎 & . & 50 & 31 o & 14 & $\mathbf{L}_{3}$ & + & 重 & 肋膜炎 & 肺結核 \\
\hline 10 & $47 \hat{\circ}$ & 24 & $\mathbf{L}$ & + & 重 & 粟粒結核 & 肺結核 & 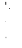 & 51 & $45 \hat{\jmath}$ & 25 & $\mathrm{~L}_{3}$ & + & 軽 & 助膜炎 & 肺炎 \\
\hline 11 & $53 \hat{\text { 。ิ }}$ & 19 & $\mathrm{~T}$ & + & 重 & " & " & & 52 & 36 § & 12 & $\mathrm{~L}_{3}$ & + & 重 & 腹膜炎 & 喉頭狹窄 \\
\hline 12 & $36 \hat{\circ}$ & 12 & $\mathbf{L}$ & $"$ & 軽 & 助膜炎 & 肺炎 & : & 53 & $42 \hat{\imath}$ & 20 & $\mathrm{~T}$ & + & 中 & 肋僧炎 & 肺焱 \\
\hline 13 & $28 \hat{\circ}$ & 14 & $\mathrm{~L}_{3}$ & + & 軽 & 肋膜茨 & 癩性喉頭狭窄 & & 54 & 39 ô & 9 & $\mathbf{L}$ & + & 重 & 粟䊉結核 & 肺炎 \\
\hline 14 & $26 \hat{\delta}$ & 6 & $\mathbf{L}$ & - & & & 瀬性喉頭狹窄 & & 55 & $27 \hat{o}$ & 2 & $\mathrm{~L}_{3}$ & + & 重 & 粟粒結核 & 肺炎 \\
\hline 15 & $56 \hat{\delta}$ & 30 & $\mathrm{~L}$ & - & & & 敬血症 & $\therefore$ & 56 & $42 \hat{\diamond}$ & 16 & $\mathrm{~T}$ & + & 車 & 粟粒結核 & 肺炎 \\
\hline 16 & 77 우 & 29 & $\mathrm{~T}$ & + & 治 & & 陽カタール & & 57 & $21 \hat{\jmath}$ & 3 & $\mathrm{~T}$ & + & 禹 & 粟粒結核 & 棜炎 \\
\hline 17 & $49 \hat{\circ}$ & 4 & $\mathrm{~T}$ & - & & （腹水） & 慢性緊炎 & & 58 & $29 \hat{o}$ & 11 & $\mathrm{~T}$ & + & 重 & 粟粒結核 & 肺炎 \\
\hline 18 & 73 응 & 3 & $\mathrm{~T}$ & - & & & 丹毒 & & 59 & 58 今ิ & 15 & $\mathrm{~L}_{3}$ & - & & & 慢性腎炎 \\
\hline 19 & $37 \hat{\circ}$ & 11 & $\mathbf{L}$ & - & & & 心臈麻瘦 & & 60 & 57 ค & 12 & $\mathrm{~L}$ & + & 重 & 粟粒結核 & 肺結核 \\
\hline 20 & 31 ㅇํㅇ & 5 & $\mathbf{L}$ & + & 重 & 肋膜炎 & 肺結核 & i & 61 & $46 \hat{o}$ & 14 & $\mathbf{T}$ & - & & & 衰弱 \\
\hline 21 & $51 \hat{\delta}$ & 12 & $\mathrm{~T}$ & + & 重 & 粟粒結核 & 肺結核 & & 62 & 23 。ิ & 9 & $\mathbf{T}$ & + & 中 & 肋膜炎 & 肺炎 \\
\hline 22 & 57 令 & 46 & $\mathrm{~T}$ & - & & （腹水） & 慢性腎炎 & & 63 & $29 \hat{\jmath}$ & 5 & $\mathrm{~L}$ & + & 軽 & 助膜災 & 衰弱 \\
\hline 23 & $39 \hat{\delta}$ & 12 & $\mathbf{L}$ & + & 重 & 肋膜炎 & 肺結核 & & 64 & 35 ○े & 11 & $\mathbf{L}$ & + & 重 & 粟粒結㤥 & 肺結核 \\
\hline 24 & 21令! & 8 & $\mathrm{~T}$ & - & & & 腸カタール & & 65 & 54 . & 21 & $\mathrm{~T}$ & + & 重 & 腹膜炎 & 肺結核 \\
\hline 25 & $36 \hat{b}$ & 9 & $T$ & + & 治 & & 急性腎炎 & & 66 & 34 各 & 10 & $\mathrm{~L}$ & + & 軽. & 肺結核, 肋膜炎 & 喉䫓狹窄 \\
\hline 26 & $45 \hat{~}$ & 14 & $\mathbf{L}$ & + & 軽 & 胃潰瘍 & 瀬性喉頭秋窄 & & 67 & 29 \& & 20 & $\mathrm{~T}$ & + & 中 & 弁膜症 & 心泼麻痹 \\
\hline 27 & $21 \hat{\delta}$ & 8 & $\mathrm{~L}_{2}$ & - & & & 瀬性喉踏秋窄 & $\therefore$ & 68 & $52 \widehat{o}$ & 22 & $\mathrm{~T}$ & + & 治 & 肋慕炎 & 流华 \\
\hline 28 & 56 우 & 4 & $\mathbf{L}$ & - & & （腹水） & 哭慛锖炎 & 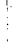 & 69 & $21 \widehat{0}$ & 14 & $\mathrm{~L}$ & + & 重 & 肋膜炎, 简結核 & 流感 \\
\hline 29 & 38 今 & 21 & $\mathbf{L}$ & + & 重 & 助膜炎 & 肺結核 & & 70 & $55 \hat{~}$ & 14 & $\mathrm{~T}$ & - & & 肝䂠変 & 脸出血 \\
\hline 30 & 31 우 & 15 & $\mathrm{~T}$ & - & & 脳出血 & 敗血粆 & & 71 & 56 우 & 14 & $\mathrm{~T}$ & - & & & \\
\hline 31 & 36 令 & 19 & $\mathrm{~T}$ & + & $4 t$ & 肺結核 & 化膿性:気管支炎 & & 72 & 43 ㅎํ & 9 & $\mathrm{~T}$ & + & 舟 & 㖴結核 & 肺結核 \\
\hline$\varepsilon 2$ & $54 \hat{\text { o }}$ & 25 & $\mathbf{L}$ & + & 重 & 粱粒結核 & 化膿性気管支炎 & & 73 & 43 ○ & 14 & $\mathrm{~L}$ & + & 重 & 助膜恣 & 肺結核 \\
\hline 33 & 46 우 & 29 & $\mathrm{~T}$ & + & 重 & 粟粒結核 & 化膿性気管支炎 & & 74 & 28 令 & 8 & $\mathrm{~L}$ & + & 重 & 肋膜炎 & 肺結核 \\
\hline 34 & $20 \lesssim$ & 5 & $\mathrm{~L}$ & + & 重 & 化膿性気、管文炎 & 化膿性気管支炎 & 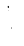 & 75 & 44 令 & 25 & $\mathrm{~L}$ & + & $4^{t}$ & 肺結核, 肋膜炎 & 脳出血 \\
\hline 35 & 33 우 & 8 & L & + & 重 & 粟粒結核 & 化膿性気管支炎 & & 76 & 48 우 & 18 & $\mathrm{~L}_{3}$ & + & 軽 & 子“出筋腫, 卵管茂瘍 & 慢性堅炎 \\
\hline 36 & $419^{\prime}$ & 10 & $\mathrm{~T}$ & - & & フレクモーネ & 晹カタル & & 77 & $32 \hat{\delta}$ & 11 & $\mathrm{~T}$ & + & 中 & 肺結核, 大動派弁口㷋窄! & 肺炎 \\
\hline 37 & $22 \hat{\jmath}$ & 5 & $\mathrm{~L}$ & + & 重 & 腸結核 & 肺結核 & $i$ & 78 & $32 \hat{\delta}$ & 4 & $\mathrm{~T}$ & + & 重。 & 肺結核 & 脸膜炎 \\
\hline 38 & 36 o & 11 & $\mathbf{L}$ & + & 重 & 粟粒結核 & 肺結核 & $\vdots$ & 79 & $49 \hat{\delta}$ & 5 & $\mathbf{T}$ & + & 治 & 肝硬変 & 脇方タル \\
\hline 39 & 25 우 & 11 & L & + & 重 & 粟粒結核 & 肺結核 & $:$ & 80 & 50 ช & 3 & $\mathrm{~L}_{3}$ & - & 重 & フレケモーネ & 肺炎 \\
\hline 40 & 35 우! & 10 & $\mathbf{L}$ & + & 中 & 肋膜炎 & 喉頍狄窄 & & 81 & 513 & 9 & $\mathbf{T}$ & + & 重： & 腸結核 & 肺結核 \\
\hline 41 & ${ }^{57}{ }^{\circ}$ & 8 & $\mathbf{L}_{3}$ & + & & & 晹力タル & 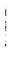 & 82 & $32+$ & 15 & $\mathbf{L}$ & + & 重： & 粟粒結核 & 肺結核 \\
\hline
\end{tabular}




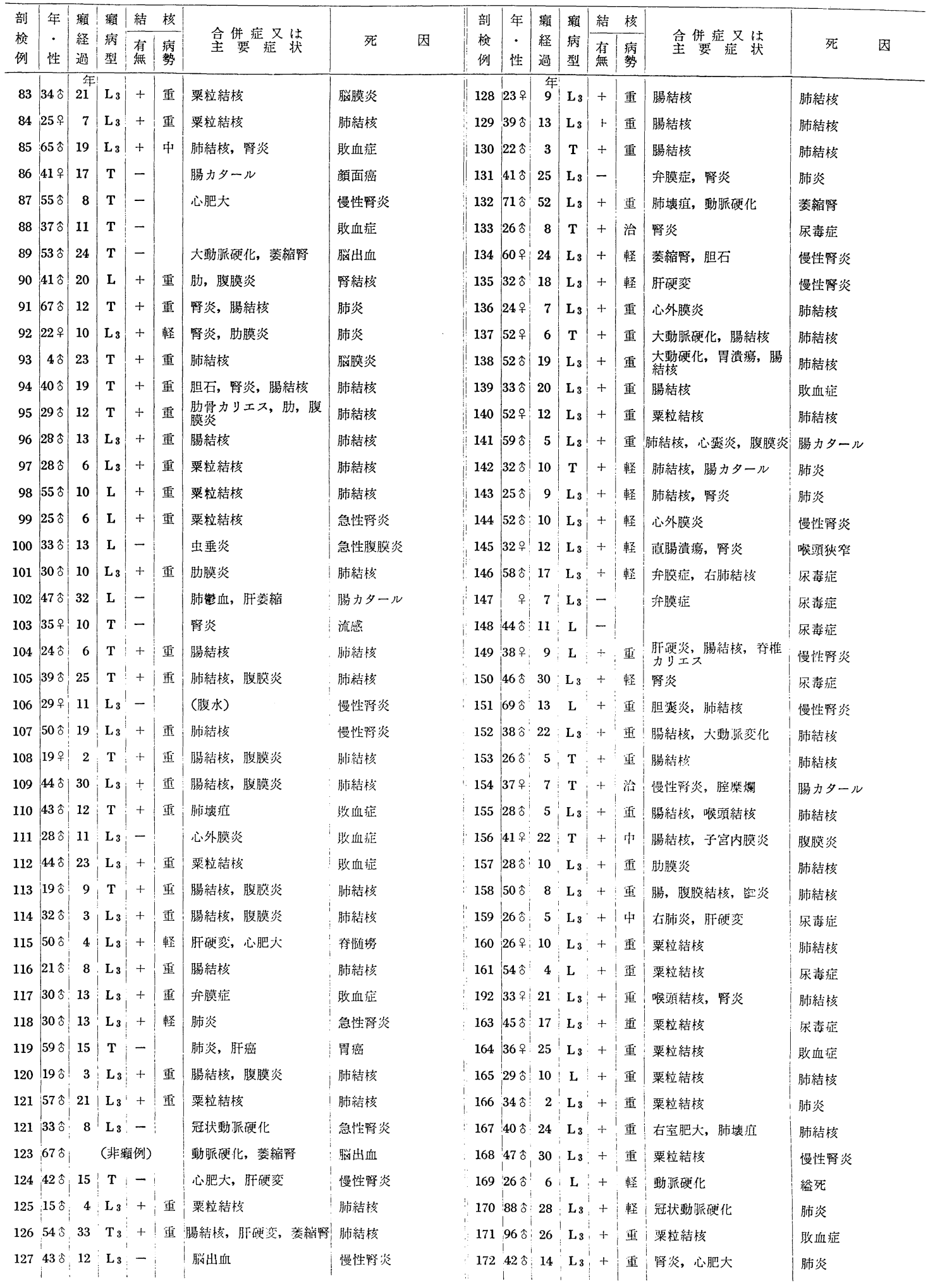




\begin{tabular}{|c|c|c|c|c|c|c|c|c|c|c|c|c|c|c|c|c|c|}
\hline 剖 & 年 & 癩 & | 癩 & 結 & 核 & & & & 剖 & 年 & 癩 & 瀬 & 結 & 核 & & & \\
\hline $\begin{array}{l}\text { 湌 } \\
\text { 例 }\end{array}$ & 性 & 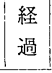 & $\begin{array}{l}\text { 病 } \\
\text { 型 }\end{array}$ & $\begin{array}{l}\text { 有 } \\
\text { 無 }\end{array}$ & 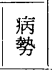 & $\begin{array}{l}\text { 合併症症 は } \\
\text { 要 状 }\end{array}$ & 死 & 因 & $\begin{array}{l}\text { 検 } \\
\text { 例 }\end{array}$ & 性 & \begin{tabular}{|l} 
経 \\
過
\end{tabular} & $\begin{array}{l}\text { 病 } \\
\text { 型 }\end{array}$ & $\begin{array}{l}\text { 有 } \\
\text { 無 }\end{array}$ & 病 & $\begin{array}{l}\text { 合併症又 は } \\
\text { 主症 状 }\end{array}$ & 死 & 因 \\
\hline 173 & $31 \hat{0}$ & 3 & $\mathrm{~T}$ & + & 重 & 粟粒結核 & 自殺 & & 218 & $36 \hat{\jmath}$ & 7 & $\mathrm{~L}_{3}$ & + & 軽 & 胃洗湟 & 的毒症 & \\
\hline 174 & $28 \hat{\partial}$ & 8 & $\mathrm{~L}_{3}$ & + & 重 & 肺結核, 堅炎 & 晹結核 & & 219 & 35 ○े & 14 & $\mathrm{~T}$ & + & 重 & 㯨粒結核 & 脳膜炎 & \\
\hline 175 & $33 \hat{o}$ & 9 & $\mathrm{~L}_{3}$ & - & & イレウス, 豎炎 & 腹膜炎 & & 220 & $48 \hat{\jmath}$ & 31 & $\mathrm{~L}_{3}$ & + & 重 & 肺結核, 留性腎炎 & 紛死 & \\
\hline 176 & 44 우 & 14 & $\mathrm{~T}$ & - & & 升膜症, 慢性肾炎 & 敗血症 & & 221 & 39 우 & 24 & $\mathrm{~L}_{3}$ & + & 重 & 慢性督炎 & 肺結核 & \\
\hline 177 & $21 \hat{b}$ & 11 & $\mathrm{~L}_{3}$ & + & 重 & 腸結核, 腎炎 & 肺結核 & & 222 & $40 \hat{s}$ & 11 & $\mathrm{~L}_{3}$ & + & 重 & 粟粒結核 & 慢性督炎 & \\
\hline 178 & $42 \hat{\jmath}$ & 20 & $\mathrm{~T}$ & + & 重 & 晹結核, 左肾結炎 & 肺結核 & & 223 & $24 . \hat{\partial}$ & 6 & $\mathrm{~L}_{3}$ & + & 中 & 慢性鳌炎 & 肺炎 & \\
\hline 179 & $47 \hat{\delta}$ & 24 & $\mathbf{L}$ & + & 重 & 腸, 腹膜結核 & 肺結核 & & 224 & $20 \hat{s}$ & 10 & $\mathrm{~L}_{3}$ & + & 重 & $\begin{array}{l}\text { 肺結核, 粟粒結核, 慢 } \\
\text { 性销学 }\end{array}$ & 肺炎 & \\
\hline 180 & $47 \hat{\delta}$ & 6 & $\mathrm{~L}$ & + & 重 & 粟粒結核, 運動脈硬化 & 敗血症 & & 225 & 33 ○ & 18 & $\mathrm{~L}_{3}$ & + & 重 & 腸結核 & 肺結校 & \\
\hline 181 & $49 \hat{\delta}$ & 42 & $\mathrm{~T}$ & + & 治 & 督炎, 腹水 & 弁膜症 & & 226 . & 45 우 & 18 & $\mathrm{~T}$ & + & 重 & 粟粒結核, 慢性腎炎 & 肋結核 & \\
\hline 182 & $5 \hat{\delta}$ & 4 & $\mathrm{~L}_{3}$ & + & 重 & 粟粒結核 & 胛膜炎 & & 227 & $31 \hat{o}$ & 26 & $\mathrm{~L}_{3}$ & + & 重 & 粟粒結核 & 肺結核 & \\
\hline 183 & $48 \hat{\partial}$ & 12 & $\mathrm{~T}$ & - & & 動脈硬化 & 脳出血 & & 228 & 33 ऽ & 16 & $\mathrm{~L}_{3}$ & + & 中 & 肺動㭽, 大動脈硬化 & 尿毒症 & \\
\hline 184 & 37 우 & 30 & I. 3 & - & & 慢性気管支炎 & 喉頭狄窄 & & 229 & $48 \delta$ & 41 & $\mathrm{~L}_{3}$ & + & 重 & $\begin{array}{l}\text { 1レウス, 慢性腎炎, } \\
\text { 腸結核 }\end{array}$ & 近結核 & \\
\hline 185 & $31 \%$ & 9 & $\mathrm{~L}_{3}$ & + & 重 & 腹膜炎 & 喉頭狹窄 & & 230 & 48 & & （非乘 & 䫛例） & & & & \\
\hline 186 & 62 운 & 10 & $\mathrm{~T}$ & + & 治 & 葠㢣腫 & 萎縮腎 & & 231 & $51 \hat{\delta}$ & 35 & $\mathrm{~L}_{3}$ & + & 重 & 腸結核, 慢性腎炎 & 肺結核 & \\
\hline 187 & $39 \hat{\delta}$ & 8 & $\mathrm{~L}_{3}$ & + & 重 & 肺結核, 僧帽弁口诙窄 & 慢性腎炎 & & 232 & $19 \hat{\jmath}$ & 3 & $\mathrm{~L}_{3}$ & + & 重 & 慢性腎炎 & 䏚結核 & \\
\hline 188 & $47 \hat{\delta}$ & 17 & $\mathrm{~L}_{3}$ & + & 軽 & 腹水, 督炎 & 肺炎 & & 233 & $36 \hat{\jmath}$ & 12 & $\mathrm{~L}_{3}$ & + & 重 & 粟粒結核, 慢性督炎 & 肺結核 & \\
\hline 189 & $76 \hat{b}$ & 11 & $\mathrm{~T}$ & + & 治 & 冠動脈硬化 & 心䉽麻瘦 & & 234 & & & （非瀨 & 撕例） & & & & \\
\hline 190 & 35 今 & 4 & $L_{3}$ & + & 重 & 督炎心外脱炎 & 肺結核 & & 235 & $37 \hat{o}$ & 10 & $\mathrm{~L}_{3}$ & + & 重 & 慢性霞炎 & 掳結核 & \\
\hline 191 & 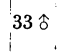 & 16 & $\mathrm{~T}$ & - & & (腹水) & 弁膜症 & & 236 & $48 \hat{~}$ & 26 & $\mathrm{~L}_{3}$ & + & 4 & 肺結核, 并膜拉 & 慢性督炎 & \\
\hline 192 & $36 \delta$ & 12 & $\mathrm{~L}_{3}$ & + & 軽 & 腎炎 & 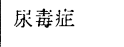 & & 237 & $60 \hat{s}$ & 16 & $\mathrm{~L}_{3}$ & - & & (腹水) & 祧表㽷 & \\
\hline 193 & 34 우 & 20 & $\mathbf{L}_{3}$ & - & & 堅出血, 子㻤膜炎 & 尿毒症 & & 238 & $28 \hat{o}$ & 19 & $\mathrm{~L}_{3}$ & + & 重 & 慢性傩炎 & 肺結核 & \\
\hline 194 & 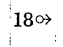 & 6 & $\mathrm{~L}_{3}$ & + & 重 & 前立腺発育不全 & 肺結核 & & 239 & $69 \hat{\delta}$ & 21 & $\mathrm{~T}$ & - & & 冠動脈硬化, 帠溃䏮 & 脳出血 & \\
\hline 195 & 34 s & 16 & $\mathrm{~L}_{3}$ & + & 重 & 心裂炎, 肋膜炎 & 肺結核 & & 240 & $34 \hat{o}$ & 16 & $\mathrm{~L}_{3}$ & + & 重 & 慢性督炎 & 肺結核 & \\
\hline 196 & $42\}$ & 12 & $\mathrm{~L}_{3}$ & + & 重 & 心外膜炎, 肝硬変 & 肺結核 & & 241 & 40 운 & 29 & $\mathrm{~T}$ & + & 重 & 粟粓結核 & 肺結核 & \\
\hline 197 & $32 \hat{o}$ & 11 & $\mathrm{~L}_{3}$ & + & 重 & 㯨粒結核 & 肺結核 & & 242 & 28 & 7 & $\mathrm{~L}_{3}$ & - & & & 縊死 & \\
\hline 198 & 38 ㅇ & 24 & $\mathrm{~T}$ & + & 重 & 粟粒結核 & 肺結核 & & 243 & $32 \widehat{o}$ & 43 & $\mathrm{~T}$ & + & 軽 & 動派硬化, 性慢珡炎 & 肺炎 & \\
\hline 199 & $52 \hat{\jmath}$ & 17 & $T$ & + & 治 & 肝硬変, 鬼眼 & 慢性㛑炎 & & 244 & $43 \hat{o}$ & 7 & $\mathrm{~L}_{3}$ & + & 中 & 蜔虫症, 肺結核 & 慢性觜炎 & \\
\hline 200 & 31 क & 9 & $\mathrm{~L}_{3}$ & + & 軽 & 肺炎, 腎炎, 腹水 & 肺炎 & & 245 & 40 우 & 11 & $\mathrm{~L}_{3}$ & + & 重 & 膀腅結核, 肺気腫 & 肺結核 & \\
\hline 201 & $32 \widehat{o}$ & 17 & $\mathrm{~L}_{3}$ & + & 重 & 督炎, 肋膜炎 & 肺結核 & & 246 & $32 \lesssim$ & 16 & $\mathrm{~L}_{3}$ & + & 重 & 胸水 & 肺結核 & \\
\hline 202 & $41 \hat{o}$ & 11 & $\mathrm{~L}_{3}$ & + & 重 & 慢性腎炎 & 肺結核 & & 247 & $37 \hat{\delta}$ & 6 & $\mathrm{~L}_{3}$ & - & & 直腸潰瘍 & 慢性篎炎 & \\
\hline 203 & $32 \hat{o}$ & 15 & $\mathrm{~L}_{3}$ & + & 中 & & 尿毒症 & & 248 & $31 \hat{0}$ & 16 & $\mathrm{~L}_{3}$ & + & 重 & 粟粒結核 & 脳膜炎 & \\
\hline 204 & 53 ㅇ & 11 & $\mathrm{~T}$ & - & & 冠動脈硬化, 大動脈硬化 & 尿毒䓑 & & 249 & $\hat{o}$ & & $\mathrm{~L}_{3}$ & + & 重 & 粟粒結核 & 尿毒症 & \\
\hline 205 & $23 \hat{\delta}$ & 7 & $\mathrm{~T}$ & + & 重 & 粟粒結核 & 肺結核 & & 250 & $31 \hat{\imath}$ & 18 & $\mathrm{~L}_{3}$ & + & 重 & 粟粒結核 & 肺結核 & \\
\hline 206 & 43 우 & 21 & $\mathrm{~L}$ & + & 重 & 慢性腎炎 & 喉頭狄窄 & & 251 & $60 \hat{s}$ & 20 & $\mathrm{~T}$ & - & & 肺整血 & 慢性腎炎 & \\
\hline 207 & $44 \hat{\text { o }}$ & 21 & $\mathrm{~L}_{3}$ & + & 重 & 粟粒結核 & 慢性掔炎 & & 252 & $28 \hat{0}$ & 21 & $\mathrm{~L}_{3}$ & + & 重 & 慢性腎炎 & 肺結核 & \\
\hline 208 & 53 ㅇ & 39 & $\mathrm{~T}$ & + & 重 & 腸漬演, 子宮内膜炎 & 肺結核 & & 253 & 33 s & 7 & $\mathrm{~L}_{3}$ & + & 重 & 腸結核 & 肺結核 & \\
\hline 209 & $35 \hat{\circ}$ & 9 & $\mathrm{~T}$ & + & 重 & 鋫粒結核 & 喉頭狄案 & & 254 & 28 & 10 & $\mathrm{~L}_{3}$ & + & 重 & 腸結核, 慢性腎炎 & 肺結核 & \\
\hline 210 & $24 \hat{s}$ & 5 & $\mathrm{~T}$ & + & 治 & 朋硬変 & 脳苂 & & 255 & $21 \hat{\delta}$ & 10 & $\mathrm{~T}$ & + & 重 & 晹結核 & 肺結核 & \\
\hline 211 & 25 ڤิ & 8 & $\mathrm{~L}_{3}$ & + & 重 & 慢性掔炎, 腸結核 & 脯結核 & & 256 & $27 \hat{\delta}$ & 9 & $\mathrm{~T}$ & + & 重 & 粟粒結核 & 肺結核 & \\
\hline 212 & $41 \hat{\text { s! }}$ & 16 & $\mathrm{~L}_{3}$ & + & 重 & 晹結核, 軣粒結蕵 & 肺結㤥 & & 257 & $36 \hat{\delta}$ & 7 & $\mathrm{~L}_{3}$ & + & 重 & 粟粒結棌 & 录毒泟 & \\
\hline 213 & 44 令. & 25 & $\mathrm{~L}_{3}$ & + & 重 & 栵粒結核 & 肺結核 & & 258 & $28 \curvearrowright$ & 10 & $\mathrm{~L}_{3}$ & + & 重 & 腸, 腹結核, 慢性掔炎 & 肺結核 & \\
\hline 214 & 44 응 & 25 & $\mathrm{~L}_{3}$ & $i^{+}$ & 重 & 粟粒結核 & 肺結核 & & 259 & $\hat{o}$ & & $\mathrm{~L}_{3}$ & + & 重 & 肺結核 & 咽頭陝得 & \\
\hline 215 & 73 क & 39 & $\mathrm{~T}:$ & - & & 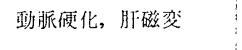 & 脳山i血 & & 260 & $56 \hat{b}$ & 4 & $\mathrm{~T}$ & - & & (腹水) & 腹膜炎 & \\
\hline 216 & 27 个 & 8 & $\mathrm{~L}_{3}:$ & - & & 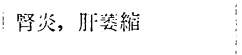 & 晹カタール & & 261 & 263 & 9 & $\mathrm{~L}_{3}$ & + & 獸 & 慢性:杫炎 & 肺結梳 & \\
\hline 217 & $i^{30 \hat{\delta}}$ & 28 & $\mathrm{~L}_{3}$ & - & & & 急性铩炎 & & 262 & $\hat{o}$ & & $\mathrm{~L}_{3}$ & + & 经! & 肍膜炎 & 疗毒惊 & \\
\hline
\end{tabular}




\begin{tabular}{|c|c|c|c|c|c|c|c|c|c|c|c|c|c|c|c|c|c|}
\hline $\begin{array}{l}\text { 剖 } \\
\text { 検 } \\
\text { 例 }\end{array}$ & $\begin{array}{c}\text { 年 } \\
\cdot \\
\text { 性 }\end{array}$ & $\begin{array}{l}\text { 癩 } \\
\text { 経 } \\
\text { 過 }\end{array}$ & $\mid \begin{array}{l}\text { 㿗 } \\
\text { 病 } \\
\text { 型 }\end{array}$ & \begin{tabular}{|l} 
結 \\
有 \\
無
\end{tabular} & $\begin{array}{l}\text { 核 } \\
\text { 病 } \\
\text { 勢 }\end{array}$ & $\begin{array}{l}\text { 合䅗症又症状 } \\
\text { 要 }\end{array}$ & 死 & 因 & $\begin{array}{l}\text { 剖 } \\
\text { 検 } \\
\text { 例 }\end{array}$ & $\begin{array}{c}\text { 年 } \\
\text { · } \\
\text { 性 }\end{array}$ & $\mid$\begin{tabular}{|l|} 
癩 \\
経 \\
過
\end{tabular} & $\mid$\begin{tabular}{|l|} 
癩 \\
病 \\
型
\end{tabular} & $\begin{array}{l}\text { 結 } \\
\text { 有 } \\
\text { 無 }\end{array}$ & $\begin{array}{l}\text { 核 } \\
\text { 病 } \\
\text { 䏻 }\end{array}$ & $\begin{array}{l}\text { 拿併症又症状 } \\
\text { 将 }\end{array}$ & 死 & 因 \\
\hline 263 & 49 के & 8 & L & + & 軽 & 陰雚水腫 & 尿毒症 & & 308 & q & & $\mathrm{L}_{3}$ & + & 重 & 腎炎 & 肺結核 & \\
\hline 264 & $34 \hat{o}$ & 15 & $\mathbf{T}$ & + & 重 & 腹膜炎 & 肺結核 & & 309 & $\hat{o}$ & & $\mathbf{L}_{3}$ & + & 重 & 膿胸, 晹結核 & 肺結核 & \\
\hline 265 & $40 \hat{\delta}$ & 15 & $\mathbf{L}$ & + & 軽 & 腹水, 肋膜炎 & 敗血症 & & 310 & $\hat{\jmath}$ & & $\mathrm{L}_{3}$ & - & & 腹水, 大動脈硬化 & 慢性腎炎 & \\
\hline 266 & $55 \hat{o} 2$ & 21 & $\mathrm{~L}_{3}$ & + & 軽 & 心肥大, 功膜炎 & 肺炎 & & 311 & ㅇ & & $\mathbf{T}$ & - & & 弁膜症, 動脈硬化 & 尿毒聇 & \\
\hline 267 & $36 \hat{b}$ & 20 & $\mathrm{~L}_{3}$ & + & 重 & 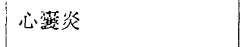 & 腓結核 & & 312 & 운 & & $\mathrm{L}_{3}$ & + & 重 & 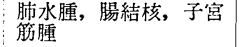 & 慢性堅炎 & \\
\hline 268 & $35 \hat{\delta}$ & 15 & $\mathrm{~L}$ & + & 軽 & 助膜炎 & 心内膜炎 & & 313 & $\hat{o}$ & & $\mathrm{~T}$ & + & 中 & 心外膜炎 & 慢性腎炎 & \\
\hline 269 & $33 \hat{8}$ & & $\mathbf{L}$ & + & 重 & 粟粒結核 & 肺結核 & & 314 & 53 우 & & $\mathrm{L}_{3}$ & + & 重 & 慢性腎炎 & 肺結核 & \\
\hline 270 & $19 \hat{\delta}$ & & $\mathrm{L}_{3}$ & + & 重 & 陽結核 & 肺結核 & & 315 & $\hat{o}$ & & $\mathrm{~L}_{3}$ & + & 重 & 慢性腎炎 & 肺結核 & \\
\hline 271 & 31 令 & & $\mathbf{T}$ & + & 重 & 粟粒結核 & 胃潰瘍 & & 316 & $\hat{o}$ & & $\mathrm{~L}_{3}$ & + & 重 & 粟粒結核 & 肺結核 & \\
\hline 272 & $42 \hat{o}$ & & $\mathrm{~L}_{3}$ & - & & 動脈砋化 & 脳出血 & & 317 & $\hat{o}$ & & $\mathrm{~T}$ & + & 中 & 助膜炎 & 右室不全 & \\
\hline 273 & $\hat{o}$ & & $\mathrm{~L}_{3}$ & + & 軽 & 胃出血 & 氺毒症 & & 318 & $59 \hat{o}$ & & & & & 動脈硬化, 慢性腎炎 & 肺結核 & \\
\hline 274 & $\hat{0}$ & & $\mathbf{L}$ & + & 重 & 䅇粒結核 & 肺結核 & & 314 & $\hat{o}$ & & $\mathrm{~L}_{3}$ & - & & $\begin{array}{l}\text { 心内膜炎, 大動脈閉銷 } \\
\text { 不全 }\end{array}$ & 慢性腎炎 & \\
\hline 275 & & & $\mathbf{L}$ & - & & & 慢性腎炎 & & 320 & 우 & & $\mathrm{L}_{3}$ & - & & 動㟲硬化, 左室不全 & 慢性腎炎 & \\
\hline 276 & $61 \hat{\delta}$ & & L & + & 重 & 粟粒結核 & 肺結核 & & 321 & $\hat{o}$ & & $\mathrm{~L}_{3}$ & + & 重 & 慢性腎炎, 胃潰瘍, 腹水 & 肺結核 & \\
\hline 277 & $\hat{o}$ & & $\mathbf{T}$ & + & 治 & 前立腺肥大 & 慢性腎炎 & & 322 & $\hat{o}$ & & & + & 巾 & 大動振脈閉銷不全 & 慢性督炎 & \\
\hline 278 & & & & + & 重 & 肺結核 & 脳膜炎 & & 323 & $\hat{o}$ & & & + & 中 & 腸結核 & 慢性䐌炎 & \\
\hline 279 & 34 o & & $\mathrm{L}_{3}$ & + & 重 & 粟粒結核 & 肺結核 & & 324 & $\hat{o}$ & & $\mathrm{~L}_{3}$ & + & 重 & 腹水, 大動派硬化, 慢 & 肺結核 & \\
\hline 280 & $33 \hat{8}$ & & $\mathrm{~L}_{3}$ & + & 重 & 右室㹡大, 肺結核 & 喉頭狄窄 & & 325 & ? & & & - & & $\begin{array}{l}\text { 慢抄耧炎, 肝硬変, 動 } \\
\text { 脈硬化 }\end{array}$ & 肺炎 & \\
\hline 281 & $\hat{\delta}$ & & $\mathbf{L}_{3}$ & + & 軽 & 右肺結核 & 喉頭狭窄 & & 326 & $\hat{o}$ & & $\mathrm{~L}_{3}$ & + & 中 & 肋膜炎, 腹水, 肺結核 & 慢性督炎 & \\
\hline 282 & $31 \hat{\partial}$ & & $\mathrm{L}_{3}$ & + & 重 & 腸結核 & 肺結核 & & 327 & $38 \hat{\delta}$ & & $\mathrm{T}$ & + & 重 & 腸結核 & 肺結核 & \\
\hline 283 & $\hat{o}$ & & $\mathrm{~L}_{3}$ & + & 重 & 腸結核, 慢性㹂炎 & 肺結核 & & 328 & $38 \hat{o}$ & & $\mathrm{~L}_{3}$ & + & 重 & 慢性䝳炎 & 肺結核 & \\
\hline 284 & 32 ๙ & & $\mathrm{L}$ & + & 重 & 肺結核 & 縊死 & & 329 & 우 & & $\mathrm{L}$ & + & 重 & 晹, 腹膜結㤥 & 肺結核 & \\
\hline 285 & $62 \delta$ & & $\mathrm{L}$ & - & & 大動脈硬化, 前立腺硬化 & 肺絬核 & & 330 & $35 \hat{b}$ & & $\mathrm{~L}_{3}$ & + & 重月 & 腸, 腹朕結核, 慢性督炎 & 肺結核 & \\
\hline 286 & $40 \hat{~}$ & & $\mathrm{~L}_{3}$ & + & 中 & 肋膜炎 & 䅬死 & & 331 & $33 \delta$ & & $\mathrm{L}_{3}$ & + & 重 & 粟粈結核, 慢性腎炎 & 肺結核 & \\
\hline 287 & $33 \hat{\delta}$ & & $\mathrm{L}_{3}$ & + & 重 & 腸結核 & 肺結核 & & 332 & $42 \hat{o}$ & & $\mathrm{~T}$ & + & 重 & 肺結核, 腸潰瘍 & 慢性腎炎 & \\
\hline 288 & 35 웅 & & $\mathrm{L}$ & + & 軽 & 肾結核, 腹水, 慢性䨒炎 & 肺結核 & & 333 & 77 우 & & $\mathrm{T}$ & + & 治 & 慢性野炎, 動挀硬化 & 脳出血 & \\
\hline $289:$ & 39 우 & & $\mathrm{L}_{3}$ & + & 重 & 慢性腎炎 & 肺結核 & & 334 & 33 ㅇ & & $\mathrm{L}_{3}$ & + & 重 & 腸結核, 慢性督炎 & 肺結核 & \\
\hline 290 & $36 \overbrace{}^{\vdots}$ & & $\mathrm{L}_{3}$ & + & 重 & 腸結核, 慢性肾炎 & 肺結核 & & 335 & 50 今 & & $\mathrm{T}$ & + & 重 & 腸結核 & 肺結核 & \\
\hline 291 & $33 \hat{\sigma}$ & & $\mathrm{L}$. & + & 重 & 膿胸, 晹結核 & 肺結核 & & 336 & $34 \hat{\delta}$ & & $\mathrm{L}_{3}$ & + & 重 & 腸結核 & 肺結核 & \\
\hline 292 & $26 \hat{\delta}$ & 12 & $\mathrm{~T}$ & + & 重 & 膿胸, 骨盤カリエス & 肺結核 & & 337 & $23 \hat{o}$ & & $\mathrm{~L}_{3}$ & + & 重 & 晹結核, 慢性腎炎 & 尿毒症 & \\
\hline 293 & $48 \hat{b}$ & & $\mathrm{~L}_{3}$ & + & 重 & 萎縮腎 & 肺結輆 & & 338 & $61 \hat{\delta}$ & & $\mathrm{L}_{3}$ & + & 重 & 慢性督炎 & 肺結核 & \\
\hline 294 & 30 今 & & $\mathrm{L}_{3}$ & + & 重 & 腸結核, 慢性腎炎 & 肺結核 & & 339 & $65 \hat{\jmath}$ & & $\mathrm{L}$ & + & 重 & 助膜炎 & 肺結核 & \\
\hline 295 & 58 s & & $\mathrm{L}_{3}$ & - & & 萎縮督 & 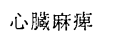 & & 340 & $23 \hat{\delta}$ & & $\mathrm{T}$ & + & 重 & 肺結核 & 碗膜炎 & \\
\hline 296 & 51 우 & & $\mathbf{T}$ & + & 重 & 雱炎, 腸結核 & 肺結核 & & 341 & 46 s & & $\mathrm{L}_{3}$ & + & 重 & 胆石敊 & 肺結核 & \\
\hline 297 & $30 \hat{s}$ & & $\mathrm{~L}_{3}$ & + & 重 & 雬粒結核 & 肺結核 & & 342 & 67 우 & & $\mathrm{T}$ & - & & & 肺炎 & \\
\hline 298 & $34 \hat{\delta}$ & & $\mathrm{L}_{3}$ & + & 重 & 慢性腈炎, 胃出血 & 肺結核 & & 343 & $73 \hat{s}$ & & $\mathrm{~T}$ & + & 中 & 大動派硬化, 肺結核 & 脳出血 & \\
\hline 299 & 30 o & & $\mathrm{T}$ & - & & 慢性腎炎, 胃粘膜出血 & 腹膜炎 & & 344 & $46 \preccurlyeq$ & & $\mathrm{L}_{3}$ & - & & 虫菲炎 & 腹膜炎 & \\
\hline 3005 & $55 \hat{\delta}$ & & $\mathrm{L}_{1}$ & - & & 肝硬変, 腹水 & 脳膜炎 & & 345 & $28 \hat{\imath}$ & & $\mathrm{L}_{3}$ & + & 重 & 肺結核 & 腹膜炎 & \\
\hline 301 & $40 \hat{\jmath}$ & & $\mathrm{L}_{1}$ & - & & 心肥大, 動派硬化 & 慢性督炎 & & 346 & 169 & & $\mathrm{~L}_{3}$ & + & 重 & 脂結㤥, 莱粒結核 & 肺結核 & \\
\hline 3026 & 65 우. & & 1 & & & 慢性捜炎, 子宫内膜炎 & 冰㤽症 & & 347 & $\hat{o}$ & & $\mathrm{~L}$ & + & 重 & 腸結核, 慢性腎炎 & 肺結核 & \\
\hline 303 & $23 \hat{\delta}$ & & $\mathrm{L}_{1}$ & + & 重 & 粟粒結核 & 肺結㤥 & & 348 & $\hat{\delta}$ & & L & - & & & 念性腎炎 & \\
\hline 304 & 30 s & & $L_{1}$ & + & 重 & 慢性督炎 & 肺結核 & & 349 & 38 名 & & $\mathrm{L}_{3}$ & + & 重 & 腸結核, 慢性㛑炎 & 肺結核 & \\
\hline 305 & $30 \hat{o}$ & & $\mathrm{~L}_{1}$ & + & 重 & 腸結核 & 肺結核 & & 350 & $60 \hat{~}$ & & $\mathrm{~L}_{3}$ & + & 重 & 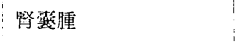 & 肺結核 & \\
\hline 3062 & 21 ? & & $\mathrm{L}_{1}$ & + & 里 & 腸結核, 腹臏焱 & 随繀核 & & 351 & $\hat{o}$ & & $\mathrm{~L}_{3}$ & + & 殴 & 督結核, 肺結核 & 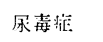 & \\
\hline 307 & 54 ठ & & $\mathrm{L}_{3}$ & + & 重 & $\begin{array}{l}\text { 大動挀肥厚, 䓩緼聚, } \\
\text { 結核 }\end{array}$ & 喉政狄空 & & 352 & $32 \hat{\jmath}$ & & $\mathrm{L}_{3}$ & + & 重 & 腸結核, 心装炎 & 肺結核 & \\
\hline
\end{tabular}




\begin{tabular}{|c|c|c|c|c|c|c|c|c|c|c|c|c|c|c|c|c|c|}
\hline $\begin{array}{l}\text { 剖 } \\
\text { 检 } \\
\text { 例 }\end{array}$ & \begin{tabular}{c|} 
年 \\
$\cdot$ \\
性
\end{tabular} & $\begin{array}{l}\text { 痳 } \\
\text { 病 } \\
\text { 型 }\end{array}$ & $\begin{array}{l}\text { 㩆 } \\
\text { 経 } \\
\text { 過 }\end{array}$ & \begin{tabular}{l|} 
結 \\
有 \\
無
\end{tabular} & $\begin{array}{l}\text { 核 } \\
\text { 病 } \\
\text { 等 }\end{array}$ & $\begin{array}{l}\text { 盒併症又 症 状 } \\
\text { 要 }\end{array}$ & 死 & 因 & $\begin{array}{l}\text { 剖 } \\
\text { 㭘 } \\
\text { 例 }\end{array}$ & $\begin{array}{c}\text { 年 } \\
\text { 性 }\end{array}$ & $\begin{array}{l}\text { 癩 } \\
\text { 病 } \\
\text { 型 }\end{array}$ & $\begin{array}{l}\text { 䈯 } \\
\text { 経 } \\
\text { 過 }\end{array}$ & $\begin{array}{l}\text { 結 } \\
\text { 有 } \\
\text { 無 }\end{array}$ & 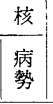 & $\begin{array}{l}\text { 合併症又住 } \\
\text { 装状症 }\end{array}$ & 死 & 因 \\
\hline 353 & 43 우 & & $\mathrm{T}$ & + & 中 & 肺結核 & 慢性䨒炎 & & 366 & $\hat{o}$ & & $\mathrm{~L}_{3}$ & + & 重 & 粟粒結核 & 肺結核 & \\
\hline 354 & $\hat{o}$ & & $T$ & + & 重 & 肋膜炎 & 肺結核 & & 367 & 우 & & $\mathrm{L}$ & & & & & \\
\hline 355 & $26 \hat{\jmath}$ & & $\mathrm{T}$ & + & 重 & 粟粒結核 & 肺結核 & & 368 & & & $\mathrm{~L}$ & & & & 腹膜炎 & \\
\hline 356 & & & $\mathrm{~L}$ & & & & & & 369 & & & $\mathrm{~L}$ & & & & & \\
\hline 357 & $\hat{o}$ & & $\mathrm{~L}$ & & & & & & 370 & & & & & & & 肺結核 & \\
\hline 358 & $49 \hat{\circ}$ & & $\mathbf{T}$ & - & & 大動脈硬化，肺水腫 & 脳出血 & & 371 & $40 \%$ & & $\mathrm{~L}_{3}$ & + & 軽 & 肋膜炎 & 肝炎 & \\
\hline 359 & & & & & & & & & 372 & $\hat{o}$ & & $\mathbf{T}$ & + & 治 & (腹水) & 慢性祭炎 & \\
\hline 360 & $52 \hat{\diamond}$ & & $\mathrm{L}_{3}$ & + & 重 & 粟粒結核 & 尿毒症 & & 373 & ? & & $\mathbf{L}_{3}$ & + & 重 & 粟粒結核，卵管垩腫 & 肺結核 & \\
\hline 361 & $63 \hat{\text { o }}$ & & $\mathrm{L}_{3}$ & + & 重 & 肺結核 & 㽷毒症 & & 374 & $\hat{o}$ & & & & & & & \\
\hline 362 & 54 상 & & $\mathrm{T}$ & + & 治 & 助膜炎 & 慢性腎炎 & & 375 & 우 & & & & & & & \\
\hline 363 & $\hat{o}$ & & $\mathrm{~T}$ & + & 重 & 慢性堅炎, 腹膜結核 & 尿毒症 & & 376 & 우 & & & & & & & \\
\hline 364 & $\hat{o}$ & & $\mathrm{~L}_{3}$ & + & 中 & 心外膜炎 & 尿毒症 & & 377 & $\hat{o}$ & & $\mathrm{~T}$ & & & & 弁膜症 & \\
\hline 365 & 우 & & $\mathrm{T}$ & - & & 動派硬化 & 慢性腎炎 & & & & & & & & & & \\
\hline
\end{tabular}

昭和 17 年 25 年

(計 68 例)

\begin{tabular}{|c|c|c|c|c|c|c|c|c|c|c|c|c|c|c|c|}
\hline 378 & $48 \hat{o}$ & & $\mathrm{~L}_{3}$ & - & & 左室肥大 & 胃潰瘍 & 408 & 우: & & L & + & 重 & 慢性腎炎, 腸結核 & 肺結核 \\
\hline 379 & $\hat{o}$ & & & & & & 肺結核 & 409 & $\hat{o}$ & & $\mathrm{~T}$ & + & 中 & 弁膜症 & 萎縮督 \\
\hline 380 & $\hat{o}$ & & & & & & 榅性掔火火 & 410 & 50 o & & $\mathrm{L}_{3}$ & - & & 㪨炎黄痘 & 急性黄色肝薮縮 \\
\hline 381 & $\hat{o}$ & & & & & & 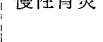 & 411 & 64 우 & & $\mathrm{L}_{3}$ & + & 重 & 慢性简炎, 肺えそ & 肺結核 \\
\hline 382 & $31 \hat{\delta}$ & & & & & 腸結核 & 肺結核 & 412 & $59 \hat{o}$ & 39 & $\mathrm{~L}_{3}$ & + & 重 & 腹膜結核, 腹水 & 脳膜炎 \\
\hline 383 & & & $\mathrm{~T}$ & + & 重 & 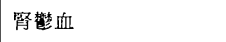 & 肺結核 & 413 & $55 \hat{\jmath}$ & & $\mathrm{T}$ & + & 治 & 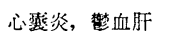 & 肺炎 \\
\hline 384 & $\hat{o}$ & & $\mathrm{~T}$ & + & 巾 & 腹水, 肺結核 & 腹膜炎 & 414 & 34 웅 & & L & - & & 萎縮特 & 胃潋 \\
\hline 385 & $35 \hat{\jmath}$ & & & & & & 肺結核 & 4.15 & $\hat{o}$ & & $\mathrm{~L}$ & + & 軽 & 心䨖掞 & 肺炎 \\
\hline 386 & $37 \hat{\delta}$ & & & & & & 肺結核 & 416 & $67 \hat{\circ}$ & & $\mathrm{T}$ & + & 治 & (腹水) & 位通溜 \\
\hline 387 & 37 우 & & & & & 晹絬核 & 肺結核 & 417 & $66 \hat{\circ}$ & & $\mathrm{T}$ & - & & (腹水) & 胃癌 \\
\hline 388 & $\delta$ & & L & + & 重 & & 肺絬核 & 418 & 53 우 & & $\mathrm{L}_{3}$ & + & 重 & 肋脱炎 & 肺結核 \\
\hline 389 & $\delta$ & & & & & & 大晹炎 & 419 & 59 우 & & $\mathrm{L}$ & - & & & 慢性简炎 \\
\hline 390 & i & & & & & & 肺結核 & 420 & 53 ڤ & & $\mathrm{L}_{3}$ & + & & 琴溃堵 & 胃潰湯 \\
\hline 391 & $\hat{o}$ & & $L$ & & & & & 421 & $39 \hat{o}$ & & $T$ & + & 重 & 心珙炎, 荬粒結核 & 慢性暂炎 \\
\hline 392 & $\hat{o}$ & & L & + & 重 & 心肥大, 右䯓結核 & 慢性等荻 & 422 & 54 운 & & $\mathrm{T}$ & - & & 驿翡炎 & 敀血埗 \\
\hline 393 & $\hat{o}$ & & & & & & 狭心症 & 423 & $58 \hat{~}$ & & $T$ & + & 軽 & 肺えそ & 攻血㖉 \\
\hline 393 & $\hat{s}$ & & L & + & 重 & 晹結核, 粟粒結核 & 肺結核 & 424 & $44 \hat{o}$ & & $\mathrm{~L}_{3}$ & + & 軽 & 慢性䦀炎 & 政血䇛 \\
\hline 395 & $\hat{o}$ & & & & 重 & 等縮肾, 粟粒結核 & 肺結核 & 425 & 60 ㅇ & 47 & $\mathrm{~T}$ & + & 軽 & & 罠澏 \\
\hline 396 & + & & & & & & 慢性㹂炎 & 426 & $29 \hat{\sigma}$ & & $T$ & - & & & 中毒 \\
\hline 397 & $\hat{o}$ & & & & & & 肺結核 & 427 & $45 \hat{\circ}$ & & L & - & & & 衰弱 \\
\hline 398 & $37 \hat{8}$ & & $\mathrm{~L}$ & + & 重 & & 肺結核 & 428 & 48 古 & & & & & & \\
\hline 399 & & & & & & & 肺結核 & 429 & $24 \hat{s}$ & & $\mathrm{~T}$ & + & 治 & & \\
\hline 400 & & & & & & & & 430 & $26 \%$ & & $\mathrm{~L}$ & + & 重 & & 肺結核 \\
\hline 401 & $\hat{\delta}$ & & & + & 重 & & 肺結核 & 431 & 54 웅 & & $\mathrm{T}$ & + & 重 & 粟粒結核 & 脳膜炎 \\
\hline 402 & $43 \hat{o}$ & & $\mathrm{~L}_{3}$ & + & 重 & 丹毒, 粟粒結核 & 急性腎炎 & 432 & $34 \%$ & & $\mathrm{~T}$ & - & & & 慢性鲟炎 \\
\hline 403 & 48 & & $\mathrm{~L}$ & + & 重 & 胆結核 & 肺結核 & 433 & $62 \%$ & & L & & & & 癌 \\
\hline 404 & $25 \hat{\delta}$ & & $\mathrm{L}_{3}$ & + & 重 & 粟粒結核 & 慢性腎炎 & 434 & $36 \hat{o}$ & & $\mathrm{~L}_{3}$ & + & 重 & 粟粒結核 & 肺絬核 \\
\hline 405 & $25 \%$ & 13 & $\mathrm{~T}$ & - & & 腹水, 心肥大督, 慗腫 & 㖟膜炎 & 435 & $47 \hat{~}$ & & $\mathrm{~L}$ & - & & & 慢性腎炎 \\
\hline 406 & $\uparrow$ & & L & & & & & 436 & 41 운 & & L & - & & & 子宮癌 \\
\hline 407 & $29 \hat{\jmath}$ & & $\mathrm{L}_{3}$ & + & 重 & 弁膜症, 腹水, 㱟炎 & 唉頭結核 & 437 & $52 \hat{\delta}$ & & & & & & \\
\hline
\end{tabular}




\begin{tabular}{|c|c|c|c|c|c|c|c|c|c|c|c|c|c|c|c|c|c|}
\hline 剖 & 年 & 糅 & 瀬 & 綘 & 核 & & & & 剖 & 年 & 㿗 & 瀬 & 結 & 核 & & & \\
\hline $\begin{array}{l}\text { 検 } \\
\text { 例 } \\
\end{array}$ & 性 & $\begin{array}{l}\text { 病 } \\
\text { 型 } \\
\end{array}$ & $\begin{array}{l}\text { 経 } \\
\text { 過 } \\
\end{array}$ & $\begin{array}{l}\text { 有 } \\
\text { 筑 } \\
\end{array}$ & $\begin{array}{l}\text { 病 } \\
\text { 势 }\end{array}$ & 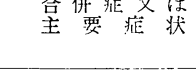 & 死 & 团 & $\begin{array}{l}\text { 检 } \\
\text { 例 } \\
\end{array}$ & 性 & $\begin{array}{l}\text { 病 } \\
\text { 型 } \\
\end{array}$ & $\begin{array}{l}\text { 経 } \\
\text { 過 } \\
\end{array}$ & $\begin{array}{l}\text { 有 } \\
\text { 無 } \\
\end{array}$ & 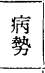 & 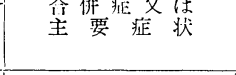 & 死 & 因 \\
\hline 438 & $43 \hat{\jmath}$ & & $L$ & + & 重 & & 肺結核 & & 446 & 54 우 & & $L_{1}$ & - & & (腹水) & 脳出血 & \\
\hline 439 & $63 \hat{\jmath}$ & & $T$ & + & 軽 & 肺癌？ & 肺炎 & & 447 & 32 우 & & $\mathrm{L}$ & + & 軽 & 無気肺, 腹水 & 慢性腎炎 & \\
\hline 440 & 42 今 & & $L$ & - & & 心肥大, 心琵炎 & 肺炎 & & 448 & $44 \hat{~}$ & & $\mathrm{~L}$ & + & 㪕 & 督膿婸, 睪丸炎 & 慢性督炎 & \\
\hline 441 & 51 우 & & $\mathrm{T}$ & - & & & 子宮癌 & & 449 & 20 今 & 10 & $\mathrm{~L}_{2}$ & + & 重 & 心筋炎, 㩔頭結核 & 慢性腎炎 & \\
\hline 442 & $38 \hat{\diamond}$ & & L & - & & & 慢性筒炎 & & 450 & $23 \hat{\jmath}$ & 12 & $T$ & + & 重 & 粟粒結核, 脊椎カリエス & 兴膜炎 & \\
\hline 443 & $60 \hat{o}$ & & L & & & & 食道癌 & & 451 & 40 ○ & & & & & 腹脱結核, 睢㨦 & 第結核 & \\
\hline 444 & & & $\mathrm{~L}_{1}$ & & & & & & 452 & 23 우 & & $\mathrm{L}_{3}$ & + & 重 & 粟粒結核 & 肺結核 & \\
\hline 445 & 20 우 & & $\mathrm{L}_{1}$ & + & 重 & 粟粒結核 & 脳膜炎 & & & & & & & & & & \\
\hline
\end{tabular}

昭和 26 年 34 年

(計 38 例)

\begin{tabular}{|c|c|c|c|c|c|c|c|c|c|c|c|c|c|c|c|}
\hline 453 & $49 \hat{\delta}$ & & $T$ & + & 治 & (腹水) & 胃癌 & 472 & 51 人 & 17 & L & + & 重 & 肺炎, 幽門猍窄 & 肺結核 \\
\hline 454 & 769 & & $T$ & - & & & 腹膜炎 & 473 & $38 \hat{o}$ & & $\mathrm{~L}$ & + & 軽 & 高皿圧, 貧血 & 慢性督炎 \\
\hline 455 & 43 ㅇ & & L & + & 㪕 & ネフローゼ & 肺炎 & 474 & & & & & & 胃潰湯, 心内膜炎 & \\
\hline 456 & 49 우 & & $\mathrm{T}$ & - & & 肺えそ & 慢性䐌炎 & 475 & 44 요 & & $\mathrm{L}_{3}$ & + & 重 & & 肺結核 \\
\hline 457 & $28 \hat{o}$ & & $\mathrm{~L}_{3}$ & + & 軽 & 肺結核, 大動派硬化 & 心筋炎 & 476 & $55 \hat{\jmath}$ & 7 & $\mathrm{~L}$ & - & & 脂肪心 & 敗血婝 \\
\hline 458 & 409 & & $\mathrm{~L}_{3}$ & + & 軽 & 心矮変性 & 衰弱 & 477 & $42 \hat{o}$ & 6 & $\mathrm{~T}$ & - & 巾 & 心肥大, 肺之そ，肺気腫 & 食中毒 \\
\hline 459 & 65 우 & & $\mathrm{T}$ & - & & 卵管繁腫 & 腹膜炎 & 478 & $42 \hat{o}$ & & $\mathbf{T}$ & + & 中 & 胃潰檫 & 慢性督炎 \\
\hline 460 & $66 \hat{\jmath}$ & & $\mathrm{T}$ & + & 攲 & 黄疽 & 肝炎 & 479 & $60 \%$ & & $\mathrm{~T}$ & - & & 高血圧 & 慢性督炎 \\
\hline 461 & 72 우 & & $\mathrm{T}$ & - & & & 膵䠞率死 & 480 & $68 \hat{o}$ & 45 & $\mathrm{~L}$ & + & 重 & 大動挀硬化 & 肺結核 \\
\hline 462 & $26 \hat{\delta}$ & & $\mathrm{L}_{3}$ & + & 重 & 喉頭結核 & 肺結核 & 481 & $46 \hat{\jmath}$ & & & & & & 胃癌 \\
\hline 463 & 39 숭 & & $\mathrm{T}$ & - & & 虫垂炎, 腹膜炎 & 肺炎 & 482 & $73 \hat{s}$ & & & & & 肝硬公 & \\
\hline 464 & 40 우 & 13 & $\mathrm{~L}_{3}$ & + & 重 & 肝缅变, 胃潰場 & 肺結核 & 483 & 58 今 & 11 & $\mathrm{~L}_{2}$ & - & & 胆石, 大動挀硬化 & 慢性督炎 \\
\hline 465 & $63 \hat{\jmath}$ & 31 & $\mathrm{~T}$ & + & 重 & & 肺結核 & 484 & $47 \hat{o}$ & 12 & $\mathrm{~T}$ & + & 軽 & 肺えそ, 肺結核 & 心䐵嘛痐 \\
\hline 466 & $37 \hat{\circ}$ & 10 & L & + & 4 & 慢性督炎 & 肺えそ & 485 & $47 \hat{\delta}$ & & $\mathrm{L}_{2}$ & + & 重 & & 肺結㤥 \\
\hline 467 & $62 \hat{8}$ & 16 & $\mathrm{~T}$ & :- & 重 & 腹膜結核, 萎縮臂 & 心嗗惏㾴 & 486 & 58 우 & & $\mathrm{L}$ & + & 重 & & 肺結核 \\
\hline 468 & $\hat{\delta}$ & & L & + & 重 & 晹結核 & 肺結核 & 487 & $42 \hat{\jmath}$ & & $L$ & - & & & 脸出血 \\
\hline 469 & $38 \hat{\jmath}$ & & $\mathrm{L}_{3}$ & + & 重 & $\begin{array}{l}\text { 腸結核, 肝炎, 心不全 } \\
\text { 蚟出症 }\end{array}$ & 肺結核 & 488 & $74 . \hat{o}$ & 7 & $\mathrm{~L}_{3}$ & + & 重 & 肝硬变 & 肺結核 \\
\hline 470 & $20 \hat{s}$ & 23 & $T$ & + & 治 & 肝硬变 & 慢性腎炎 & 486 & $47 \hat{o}$ & 34 & $T$ & + & 治 & 動派硬化, 高血圧 & 脳幽血 \\
\hline 471 & $41 \hat{0}$ & 21 & $\mathrm{~L}_{3}$ & + & 軽 & & 心淢楿㾯 & 490 & 57 우 & 37 & $\mathrm{~L}$ & - & & 肝硬変, 腹膜炎 & 急性腎炎 \\
\hline
\end{tabular}


表 2 第二観察群（国立療養所大島青松園）全剖検例450例について

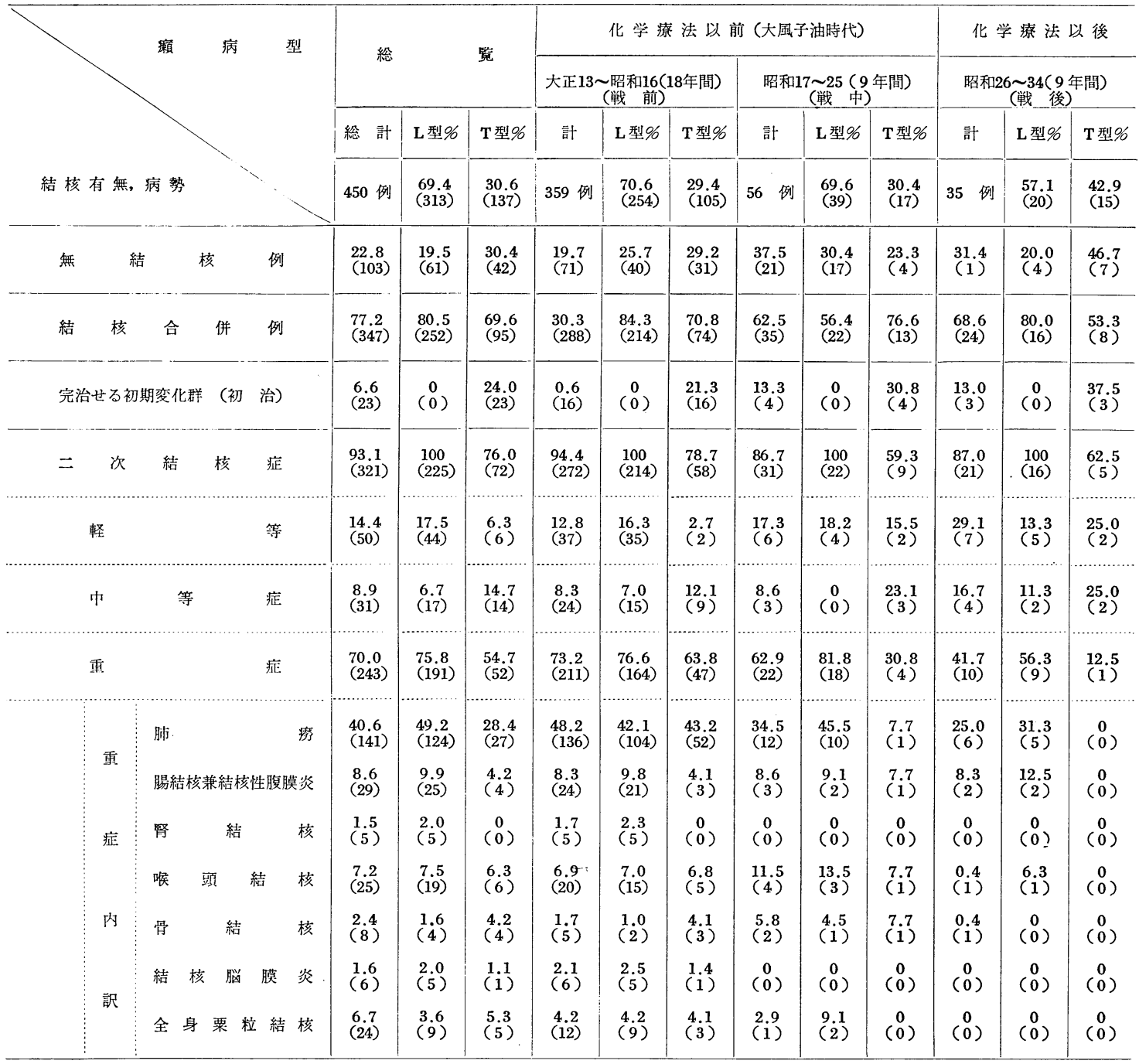

（括弧内は実数を示す） 
表 3 臓器別に見た瀨屍結核病勢一覧

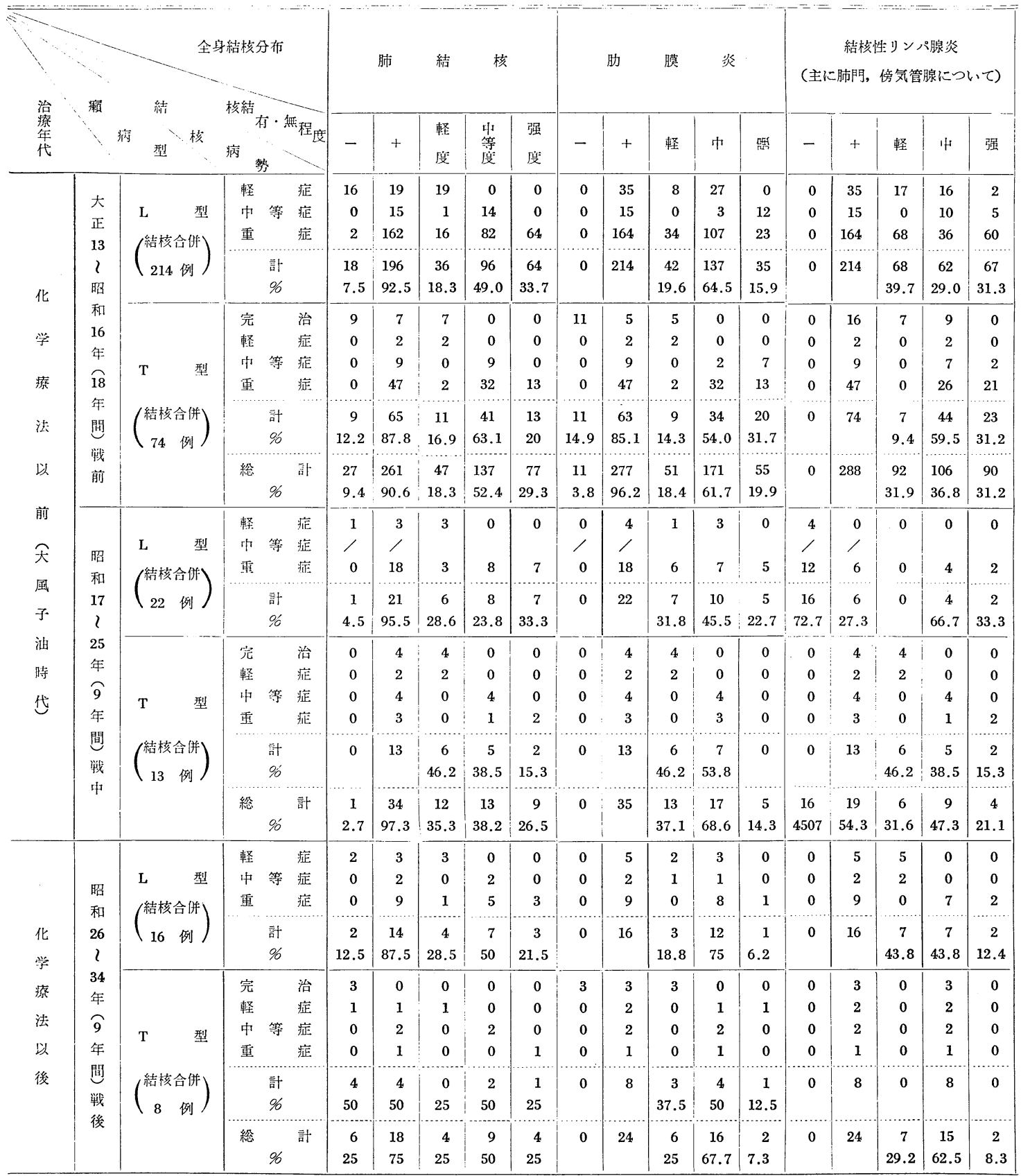


表 3 （続き）

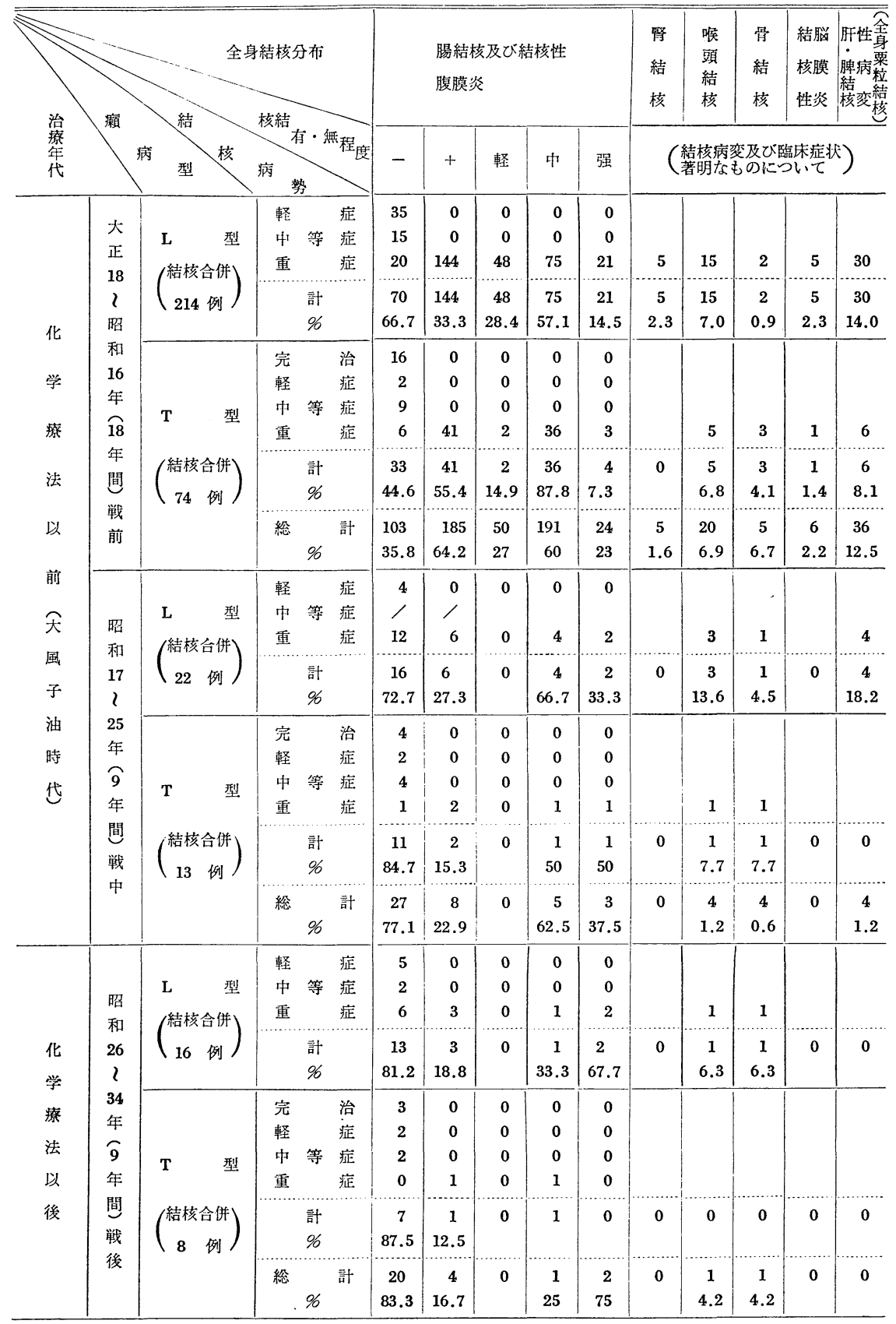


表 4 攋屍結核合併状治総括

\begin{tabular}{|c|c|c|c|c|c|c|c|c|c|c|c|c|c|c|}
\hline & & & \multicolumn{3}{|c|}{ 化学療法以前（戦前） } & 359 例 & \multicolumn{8}{|c|}{ 化学療法以後 (戦後) 101 例 } \\
\hline & & & $\mathbf{L}$ & 型 & $\mathrm{T}$ & 型 & $\mathbf{L}$ & 型 & 大扂群 & 56破群 & $\mathrm{T}$ & 型 & 大島群 & らい研群 \\
\hline 各 & 総 & 数 & $70.6 \%$ & 254 & $29.4 \%$ & 105 & $64.4 \%$ & 65 & 20 & 45 & $35.8 \%$ & 36 & 15 & 21 \\
\hline \multirow{2}{*}{ 無 } & \multirow{2}{*}{ 核 } & \multirow{2}{*}{ 例 } & $15.7 \%$ & 40 & \multicolumn{2}{|l|}{$29.2 \%$} & $26.2 \%$ & 17 & 4 & 13 & $36.1 \%$ & 13 & 7 & 6 \\
\hline & & & \multicolumn{2}{|c|}{ 総 計 } & \multicolumn{2}{|l|}{$.8 \%$} & \multicolumn{5}{|c|}{ 総 計 } & \multicolumn{2}{|l|}{71} & \\
\hline \multirow{2}{*}{ 結 } & \multirow{2}{*}{ 併 } & \multirow{2}{*}{ 例 } & $84.3 \%$ & 214 & \multicolumn{2}{|l|}{$70.8 \%$} & $73.8 \%$ & 48 & 16 & 32 & $63.9 \%$ & 23 & 8 & 15 \\
\hline & & & \multicolumn{2}{|c|}{ 総 計 } & \multicolumn{2}{|c|}{288} & \multicolumn{5}{|c|}{ 総 計 } & \multicolumn{2}{|l|}{71} & \\
\hline \multicolumn{3}{|c|}{ 完治せる初期変化群 } & $0 \%$ & 0 & $21.3 \%$ & 16 & $0 \%$ & 0 & 0 & 0 & $65.2 \%$ & 15 & 3 & $80 \% \quad 12$ \\
\hline \multirow[t]{4}{*}{$=$} & 次 結 核 & 症 & $100 \%$ & 214 & $78.7 \%$ & 58 & $100 \%$ & 48 & 16 & 32 & $34.8 \%$ & 8 & 5 & $20 \% 6 \quad 3$ \\
\hline & 軽 & 症 & $16.3 "$ & 35 & $2.7 "$ & 2 & $45.8^{\prime \prime}$ & 22 & 5 & 17 & $8.6 "$ & 2 & 2 & 0 \\
\hline & 中 & 症 & $7.0 "$ & 15 & $12.1 "$ & 9 & $18.8 "$ & 9 & 2 & 7 & $21.5 "$ & 5 & 2 & 3 \\
\hline & 重 & 症 & $76.6^{\prime \prime}$ & 164 & $63.8 "$ & 47 & $35.4 \prime \prime$ & 17 & 9 & 8 & $4.3 "$ & 1 & 1 & 0 \\
\hline & \multicolumn{2}{|l|}{ 肺疾 } & $42.1 "$ & 104 & $43.2 "$ & 32 & $14.6 ”$ & 7 & 5 & 2 & & & & \\
\hline 重 & \multicolumn{2}{|l|}{ 腸結核及結核性腹膜炎 } & $9.8^{\prime \prime}$ & 21 & $4.1 "$ & 3 & $14.6 "$ & 7 & 2 & 5 & & & & \\
\hline \multirow[t]{2}{*}{ 症 } & 堅＼cjkstart結 & 核 & $2.3^{\prime \prime}$ & 5 & $0 "$ & 0 & $0 "$ & 0 & 0 & 0 & & & & \\
\hline & 㗋 頭 結 & 核 & $7.0 "$ & 15 & $6.8 "$ & 5 & $2.1 "$ & 1 & 1 & 0 & & & & \\
\hline 内 & 骨 & 核 & $1.0 "$ & 2 & $4.1 "$ & 3 & $4.2 "$ & 2 & 1 & 1 & $4.3 "$ & 1 & 1 & 0 \\
\hline 訳 & 結核性脳膜 & & $2.5 "$ & 5 & $1.4 "$ & 1 & $0 "$ & 0 & 0 & 0 & & & & \\
\hline & 全身粟粒結 & & $4.2 "$ & 9 & $4.1 "$ & 3 & $0 "$ & 0 & 0 & 0 & & & & \\
\hline
\end{tabular}

